\title{
Choosing a Thirteenth-Century Motet Tenor: From the Magnus liber organi to Adam de la Halle
}

\author{
CATHERINE A. BRADLEY
}

Medieval motets are characterized by their use of plainchant tenors, quotations from the established Latin-texted melodies for the Christian liturgy that form the basis of new polyphonic compositions, in Latin and in the French vernacular. The significance of motet tenors is long established: the late thirteenth-century theorist Johannes de Grocheio likened a tenor to the foundations of a house or the bones that give structure to the body, ${ }^{1}$ while in the fourteenth century, Egidius de Murino advised that the tenor of a motet should be chosen first and the upper voices then fashioned to accord with its subject matter ("materia"). ${ }^{2}$ These remarks by medieval theorists have been much cited in modern scholarship, which has richly demonstrated and explored the considerable semantic potential of tenor quotations in motets, as well as their importance in supporting complex, large-scale, so-called isorhythmic structures characteristic of the fourteenth-century ars nova. ${ }^{3}$ By contrast, the more explicitly musical

I wish to thank David Maw for extensive and invaluable discussions of this material, and am indebted to Elizabeth Eva Leach, Mark Everist, and the anonymous readers of this Journal for their comments and suggestions. Parts of this article were presented at the Yale Song Lab, 2014; the Medieval and Renaissance Music Conference, Birmingham, UK, 2014; the annual meeting of the American Musicological Society/Society of Music Theory, Milwaukee, 2014; the symposium "Ars Antiqua III: Music and Culture in Europe, c. 1150-c. 1330," Lucca, 2018; the Colloquium series at the Music Faculty of the University of Cambridge, 2019; the conference "Música y contextos en el mundo ibérico medieval y renacentista," Borja, Zaragoza, 2019; as a keynote lecture at the Theory and Analysis Graduate Students Conference of the Society for Music Analysis, Edinburgh, 2019; the conference “Compositeur(s) au Moyen Âge," Université de Rouen, 2019; and the Medieval and Renaissance Music Conference, Basel, 2019. I gratefully acknowledge the support of the EURIAS Fellowship programme (cofunded by Marie Skłodowska-Curie Actions under Framework Programme 7) and the Institut d'études avancées de Paris.

${ }^{1}$ Johannes de Grocheio, Ars musice, 86-87.

2 See the translation of Murino's De modo componendi in Leech-Wilkinson, Compositional Techniques, 1:21.

${ }^{3}$ On the semantic potential of tenor quotations in motets, see especially Huot, Allegorical Play. For a summary of the traditional conceptualization of tenors as structural foundations in 
functions and compositional treatments of tenor quotations in thirteenth-century ars antiqua motets that are the focus of the current article have received comparatively little scholarly attention. Previous considerations of tenor "families" - groups of compositions based on the same plainchant quotation-have illuminated shared compositional characteristics in particular cases,${ }^{4}$ but it remains difficult to gain a broader sense of trends in tenor selection across the thirteenth century, or of the reasons why certain plainchant melodies enjoyed considerable popularity as the foundations of motets while others faded from use entirely. ${ }^{5}$ This article establishes and rationalizes tenor behaviors particular to vernacular motets-as distinct from the earlier traditions of liturgical organum and clausula composition from which Latin and French motets inherited their stock of plainchant melodies for polyphonic elaborationbehaviors motivated by musico-poetic forms, techniques, and quotations strongly associated with vernacular songs.

A focus on the choice and treatment of plainchant melodies particular to French-texted motets might seem to entrench the straightforward opposition of sacred Latin and secular vernacular spheres that has characterized conventional narratives of thirteenth-century motet development. According to these narratives, the motet began as a sacred Latin genre, which

ars nova motets, see Zayaruznaya, Upper-Voice Structures, 11-21. Zayaruznaya's book, published after this article was accepted for publication, challenges the perceived foundational role of the tenor in fourteenth-century motets, arguing that tenors are often shaped not at the outset of a compositional process, but in response to planned upper-voice structures. Her thesis is complementary to that espoused by the current study for ars antiqua motet tenors.

${ }^{4}$ The practice of examining a complex or family of interrelated motets that share the same musical material is well established; see, for example, Baltzer, "Polyphonic Progeny," and Planchart, “Flower's Children.” Large-scale studies of broader tenor families, considering multiple different motet compositions on the same tenor, are less common. Two notable exceptions are Pacha, "VERITATEM Family,” and Klaus Hofmann's book-length study of the thirteenth century's most widely used tenor, IN SECULUM: Hofmann, Untersuchungen zur Kompositionstechnik. The semantic potential of this Easter tenor has also been explored in Rothenberg, "Marian Symbolism of Spring."

${ }^{5}$ Crocker's 1990 observation remains apposite: "Scholars have often expressed the wish to know why a few tenors were favoured; several kinds of explanations have been advanced, with varying satisfaction. For the French motet, at least, the 'liturgical' explanation seems the least useful. A more sophisticated structural analysis seems called for": Crocker, "French Polyphony," 641. 
evolved from clausulae but became increasingly detached from its liturgical origins, to the extent that a handful of late thirteenth-century motets borrowed their tenors from vernacular songs rather than plainchant. In fact, deeper engagement with the relationship between plainchant and vernacular song techniques in French motets helpfully complicates such neatly defined categories and chronologies. On the one hand, I show that tenor behaviors motivated by vernacular song idioms are an earlier phenomenon than is conventionally acknowledged, one that is evident in the first layer of manuscript witnesses to thirteenth-century polyphony, in which vernacular motets have been transformed — through the removal of their texts-into untexted clausulae. Furthermore, certain such vernacular motets adopt rhythmically very simple arrangements of their tenor plainchants, arrangements that are usually associated with much older clausulae and are considered to predate the advent of the motet: an apparently "archaic" clausula tenor arrangement is thereby combined with song-like characteristics linked to the "modern" genre of the vernacular motet. On the other hand, I underline links between motets and polyphonic rondeaux in the later thirteenth century, newly identifying a plainchant source for a tenor in a motet by Adam de la Halle, and demonstrating that this chant melisma was selected in order to facilitate a polyphonic citation from a three-voice rondeau also by Adam. These circumstances force a rethinking of current understandings of stylistic features and generic categories in the thirteenth century, and establish a more complicated and interdependent relationship between sacred and secular materials.

This article argues that certain short and musically unremarkable chant melodies that had not previously been objects of polyphonic interest were selected as thirteenth-century French motet tenors precisely because of their lack of a distinctive or complex musical character. The simplicity and brevity of these plainchant tenors, typically circling around the same circumscribed pitches, facilitated their successful combination with independent compositional procedures established in vernacular song and with other musical quotations. Such tenors resemble, in their flat melodic profile, not only the lowest voices of polyphonic rondeaux, but also the pes (literally "foot") commonly employed in late thirteenth- and early fourteenthcentury English motets-a simple and repetitive harmonic underpinning, moving at a slower rate than the upper voices, and usually oscillating between two tonal poles. Crucially, and like the lowest voices of polyphonic rondeaux, pedes — though highly generic-are fashioned for or adapted to individual motets: they are not quotations of plainchant or of any other preexisting melodies. Given the existence of such simple harmonic schemes as the foundations of motet compositions, it is all the more remarkable that the creators of vernacular motets did not simply dispense with the convention that a tenor should be a plainchant quotation. On the contrary, they prized this convention and its attendant aesthetics so highly as to seek out bland and 
malleable plainchant tenors, chant melodies that were sometimes so nondescript as to be barely recognizable but that had the status of genuine chant quotations nonetheless.

Such compositional behavior confirms the continued importance of plainchant foundations in motets heavily indebted to vernacular musical cultures, as well as the familiarity of motet creators with music from liturgical and vernacular traditions. The very selection of a tenor capable of accommodating predetermined vernacular song forms and refrains-short phrases of music and French text that often circulated as quotations in thirteenth-century songs and motets and in the literary genre of romances-depended on an intimate knowledge of plainchant melodies. In addition, continued insistence on the use of plainchant tenors, as well as the occasional use of vernacular song tenors, highlights the centrality of musical quotation as a compositional aesthetic in thirteenth-century motets. This article argues that motet composers, while remaining sensitive to the semantic connotations of tenor texts, also conceptualized plainchant quotations as musical objects whose ability to be combined with or stand in for other musical quotations was recognized and exploited. It illuminates the compositional techniques and aesthetic priorities of quotational play through a range of case studies, including the late thirteenth-century motet "Je ne chant" / "Talens" / APTATUR / OMNES that is uniquely based on not one but two simultaneous plainchant quotations, and motets that achieve polyphonic citations of Adam de la Halle's three-voice rondeaux through the careful selection of motet tenor quotations that resemble the freely composed lowest voices of these preexisting rondeaux. Such attitudes to tenor selection provide new and challenging perspectives on the relationship between the motet-typically considered to be the thirteenth-century's most elite and compositionally sophisticated genre-and types of polyphony that are much less well attested in written sources—such as polyphonic rondeaux and works built on pedes-and that are often considered to inhabit a more "popular" realm of musical practice.

\section{Tenor Trends in the Thirteenth Century}

The selection of motet tenors in the thirteenth century differs significantly from that in the fourteenth. While thirteenth-century motets are linked to existing practices of organum and clausula composition in the so-called Magnus liber organi, there is no parallel connection between fourteenth-century motets and any body of liturgical polyphony. Approximately onefifth of the thirteenth-century motet corpus (just over one hundred pieces) survives also in the form of melismatic clausulae, and most of the remaining motet compositions, for which related clausulae do not exist, nevertheless employ tenor chants that appear within the repertoire of clausulae and organa. More than one hundred different segments of plainchant serve as the basis of thirteenth-century motets, and a majority of these tenors feature in just one or two such 
compositions. The use of unique motet tenors was the norm in the fourteenth century, where the plainchant sources of tenors are, in addition, considerably more varied and diffuse. In contrast to fourteenth-century practices, however, thirteenth-century motets-like clausulaewere also characterized by traditions of composition on a particular tenor, with motet creators frequently returning to and reworking the same chant foundation.

Twelve tenors are found as the basis of ten or more individual thirteenth-century motet compositions (see Table 1). ${ }^{6}$ Compositional interest in the thirteenth-century's most popular tenor, IN SECULUM, was especially intense, there being almost double the number of motets on this tenor by comparison with its nearest rivals FLOS FILUS EIUS and OMNES. Such interest in IN SECULUM had a precedent in the clausulae repertoire, where this chant melisma enjoyed similar popularity, as did three other tenors favored in motets, LATUS, VIRGO, and REGNAT, all of which served as the basis of ten or more different clausulae. Connections between tenor conventions in clausulae and motets are further evinced by the fact that eight of the twelve tenors in Table 1 served as the basis of five or more independent clausulae. Only three of the twelve tenors that were prominent in the motet repertoire are found in just a single clausula or in none at all: PORTARE received a single independent clausula composition (with its alternative text SUSTINERE) in the Magnus liber in contrast to its sixteen motets; VERITATEM was the basis of only a very short setting in the layer of so-called abbreviatio clausulae or mini clausulae; ${ }^{7}$ and the widespread adoption of the tenor APTATUR was wholly exceptional. Drawn from an obscure plainchant responsory for the minor Flemish saint Winoc, APTATUR is found exclusively in the late thirteenth-century motet repertoire and does not feature at all in the Magnus liber.

${ }^{6}$ Table 1 offers a general overview of the relative popularity of tenors in motets and clausulae as well as of the relative lengths of the borrowed chant melismas. Each tenor is categorized according to its typical length: precise numbers of tenor pitches are not stated since they are often subject to slight variation (as in the case of the OMNES tenor discussed below). See also Hofmann's list of the ten most popular thirteenth-century motet tenors in his Untersuchungen zur Kompositionstechnik, 11. My selection differs slightly from Hofmann's, because he counts contrafactum reworkings of the same individual composition separately. Numbers for Mass (M) and Office $(\mathrm{O})$ chants in Table 1 and throughout the article are those established in Ludwig, Repertorium.

${ }^{7}$ Abbreviatio clausulae or mini clausulae are uniquely preserved in F. Distinct from other substitute or independent clausulae, they seem to represent short segments of discant excerpted from another organum cycle; see Bradley, Polyphony in Medieval Paris, 49-80. 
Table 1 Tenors used in ten or more thirteenth-century motet compositions

The tenors that appealed to both clausula and motet creators exhibit distinct trends in terms of their length and melodic characteristics (see Example 1). Preferred clausulae tenors, such as LATUS and REGNAT, are noticeably longer, wider-ranging, and more intricate, often with internal melodic patterns of their own (indicated by letters in Example 1). By contrast, preferred motet tenors that have minimal or no clausulae traditions-such as VERITATEM, PORTARE, and APTATUR - are on the whole shorter, more contained in range, and more locally repetitive, usually featuring multiple iterations of the tenor's home pitch or final. These latter musical characteristics also prevail in the three tenors in Example 1 that predominate in the repertoire of three-voice vernacular "double" motets recorded in later thirteenth-century sources- OMNES, PORTARE, and APTATUR. ${ }^{8}$

Example 1 Typical versions of plainchant tenors used in ten or more thirteenth-century motets

Relatively short and simple motet tenors represent a substantive proportion of the thirteenth century's most favoured motet tenors (one third of the tenors in Table 1 and Example 1), but unlike other favored tenor melodies they generally lack a corresponding tradition as the basis of clausulae and belong to an apparently later layer of thirteenth-century motet composition. This article demonstrates and seeks compositional explanations for the adoption of short and simple motet tenors, whose selection and prevalence-especially in the case of APTATUR - cannot simply be explained as an inheritance from established practices in clausulae. At the same time, it underlines fundamental connections between clausulae and motet traditions borne out by their shared basic stock of tenor melodies. As established below, later vernacular motet composers remained well aware of conventions surrounding the manipulation of the OMNES tenor in the organa and clausulae of the Magnus liber, using their knowledge of these earlier practices to facilitate song-like motet compositions.

\section{Early Examples of Short and Simple Tenors: IUSTUS and HODIE}

${ }^{8}$ I discuss in greater detail below the consistent emphasis on an $\mathrm{F}$ final in the three tenors favored in late thirteenth-century motets (OMNES, PORTARE, and APTATUR), which further sets these tenors apart from the others in Example 1. 
Two similar and musically modest plainchant melismas whose selection as the basis for motets is without precedence in earlier traditions of liturgical polyphony demonstrate a preference for short and simple tenors within the first layers of vernacular motet composition, whose musical material is recorded in the Florence manuscript (F, dated to the 1240s). The tenors IUSTUS (part of the "Alleluia. Letabitur iustus," M 49) and HODIE (part of the "Alleluia. Dies sanctificatus," M 2) received many discant settings among the organa of the Magnus liber, appearing in multiple texted guises as part of Alleluia melodies that were retexted for use on several different liturgical occasions. ${ }^{9}$ In almost all of their many appearances across the Magnus liber, these tenors never featured as the basis of independent clausulae compositions and were consistently treated to cursory and unelaborate polyphonic settings, which stated the plainchant melisma in question only once in a simple rhythmicization. ${ }^{10}$ Given the lack of any established tradition of clausula composition on these tenors, their adoption in motets seems to have been motivated by a desire to balance and unite the different musical parameters of chant and vernacular song idioms. Both of the two extant motets on IUSTUS employ repetitive song forms in their upper voices, while the single surviving motet on HODIE is a patchwork of vernacular refrain quotations.

The perfunctory setting of IUSTUS preserved within the two-voice organum setting of "Alleluia. Letabitur iustus" in $\mathbf{W}_{1}$, a manuscript dated to the 1230 s, typifies its treatment in the

${ }^{9}$ The melody of the IUSTUS (M 49) melisma is additionally found on the text GLORIOSE in "Alleluia. Nativitas" (M 38), and on GRATIA in "Alleluia. Diffusa est" (M 55). In $\mathbf{W}_{2}$, the polyphony of the M 38 organum is presented three times in succession, with two retextings unique to this source: "Alleluia. Sanctissime Iacobe" (M 60) and "Alleluia. Iudicabunt sancti" (M 42). The melody of the HODIE (M 2) melisma is additionally found on A DEXTRIS in "Alleluia. Video celos" (M 4); on SCIMUS in "Alleluia. Hic est discipulus" (M 6); and on VENIMUS in "Alleluia. Vidimus stellam" (M 10). Furthermore, within each of these individual Alleluia chants the music of the HODIE melisma is effectively presented twice, since it appears in a slightly longer form at the outset of the Alleluia verse: on DIES in M 2; VIDEO in M 4; HIC EST in M 6; VIDIMUS in M 10; and in "Alleluia. Tu es Petrus" (M 31) on TU ES (the solo verse is shorter in length in this Alleluia, such that the melisma that corresponds directly to HODIE-ECCLESIAMis part of a choral section and therefore not set polyphonically in the Magnus liber). Additionally, the longer form of the HODIE melisma is uniquely found with the text GLORIA (from "Alleluia. Gloria et honore" M 65a) in an independent clausula in F (see note 000 below).

${ }^{10}$ As I will argue below, the single independent clausula on the HODIE tenor (alternatively texted here as VENIMUS) represents a transcription of the HODIE motet. 
Magnus liber (see Example 2). ${ }^{11}$ The short discant in $\mathbf{W}_{\mathbf{1}}$ states the ten notes of the IUSTUS melisma only once: this is the usual form and treatment of the plainchant tenor found, in its various texted identities, across the Magnus liber and in thirteenth-century chant books. ${ }^{12}$ Both of the motets on IUSTUS, however, adopt a longer version of this tenor, with two added closing pitches, a and $\mathrm{G}$ (see below). ${ }^{13}$ The addition of pitches might seem at odds with the proposition that brevity was desirable in a motet tenor, but in this instance it reveals a different aspect of the IUSTUS tenor that seems to have been key to its success as a motet foundation: its multiple iterations of the pitch $\mathrm{G}$, which is opposed by a, a tone above. The IUSTUS melisma is very limited in range (spanning a fifth, from $\mathrm{F}$ to $\mathrm{c}$ ) and predominantly stepwise in melodic motion, and - in its twelve-note version - the pitches $\mathrm{G}$ and a each sound four times, usually in alternation. The tenor therefore offers multiple opportunities for cadence points on the final, $G$, which is set in contrast to a, and its circumscribed and repetitive profile could support corresponding repetitions in an accompanying upper voice.

Example 2 Discant on IU[STUS], $\mathbf{W}_{1}, 45 \mathrm{v}$

These characteristics are strongly evident in the upper voice of the motet "A grant joie" / IUSTUS (see Example 3), recorded in two mid-thirteenth-century motet sources, $\mathbf{W}_{\mathbf{2}}(224 \mathrm{r}$ )

${ }^{11}$ All transcriptions are my own. Ligatures are indicated by square brackets, conjuncturae by dashed slurs, and plicas by a line through the stem; original text spellings are retained. Capitalization, punctuation, and text line numbers are editorial. Vertical brackets indicate the editorial insertion of material that is not explicitly present in the manuscript source but can be inferred from context or convention. Musical time is measured in units of "perfection": the length of a ternary long, a dotted quarter in transcription, corresponds to one perfection.

${ }^{12}$ In addition to the discant on IUSTUS in $\mathbf{W}_{\mathbf{1}}$ and $\mathbf{F}$, there is one further mini clausula on IUSTUS. In its alternative texted guises, there are five further individual discant compositions on the melisma recorded variously in $\mathbf{W}_{1}, \mathbf{F}, \mathbf{W}_{2}$, and $\mathbf{M o}$. On only one occasion (apart from the $\mathbf{F}$ discant related to "A grant joie") does this tenor melisma appear in a double statement and in its twelve- rather than ten-note form. This is the two-voice discant on GRATIA, M 55, unique to F (142r). For a comparison of four different monophonic versions of the IUSTUS melisma, see Everist, French Motets, 95.

${ }^{13}$ I employ a system of pitch nomenclature that reflects the medieval gamut: A-G (where $\mathrm{C}$ is the $\mathrm{C}$ below middle $\mathrm{C}$ ) and $\mathrm{a}-\mathrm{g}$ (where $\mathrm{c}$ is middle $\mathrm{C}$ ). 
and $\mathbf{N}$ (196r), and-as discussed further below-uniquely preserved without its text within the context of the two-voice organum "Alleluia. Letabitur iustus" in F (138r). Unusually, the motetus "A grant joie" has a clearly defined AAB or pedes cum cauda form (reflected in the layout of Example 3) that is commonly found in the vernacular monophony of the troubadours and trouvères, and that seems here to thematize trouvère song within the generic context of the motet. ${ }^{14}$ The B material employs a similar phrase structure to the A sections, but with an additional four-perfection closing phrase, the opening of which echoes that of the A material. This tripartite musical form is complemented by the structure and poetic rhymes of the motetus text (see Table 2). ${ }^{15}$

Example 3 "A grant joie" / IUSTUS, $\mathbf{W}_{2}, 224 \mathrm{r}$

Table 2 Text and translation of "A grant joie" $\left(\mathbf{W}_{2}, 224 \mathrm{r}\right)$

Such a regular formal scheme is often limited in clausulae and motets by the demands of combining, in a satisfactory harmonic relationship, a predetermined plainchant tenor melody and an upper voice with a defined repetitive structure. In fact, the basic AAB structure is adapted slightly in "A grant joie" to include a two-perfection insertion after the first A statement (labeled X in Example 3). ${ }^{16}$ This short insertion X (perfections 7-8) seems to have been occasioned precisely because of the demands of the tenor. The tenor pitch $b$ in perfection 7 prevents the immediate repetition of the motetus's opening A material, which (since it begins on c) would have produced a stressed dissonant second. The $X$ material in perfections 7-8 allows the b-a progression in the tenor to lead, instead, to a cadence on a and to delay the repetition of the motetus's A material by two tenor pitches. This delay facilitates the reappearance of the A material over a very similar segment of the chant melody: $\mathrm{c}-\mathrm{G}-\mathrm{a}-\mathrm{G}$ in perfections 9-12, compared to F-G-a-G in perfections 1-4 (marked by boxes in Example 3, with

${ }^{14}$ Tischler cited "A grant joie" as a "fine ... example" of the sort of "clearly structured pieces" that "possibly ... were actually created by trouvères": Tischler, Style and Evolution, 1:70. On the AAB form in motets, see Saint-Cricq, "New Link."

15 The translation in Table 2 is adapted from Page, Discarding Images, 47.

${ }^{16}$ See also the analysis of "A grant joie" in Saint-Cricq, "Formes types," 2:139. This motet is excluded from consideration within Saint-Cricq's central corpus of AAB motets because of the insertion at the end of the first A section; see ibid., 1:89n4. 
differences highlighted by wavy boxes). ${ }^{17}$ The $X$ insertion makes the repetition of the motetus's A material possible, but it momentarily disrupts the regularity of the AAB form, reflecting a fundamental tension between the demands of the song form in the upper voice and the chant quotation in the tenor.

The constraints of a predetermined tenor notwithstanding, another song-like feature is achieved in the motet's upper voice. The motetus moves consistently between two different cadence types, the final pitch G, which serves as a tonally "closed" sonority, contrasting with the more "open" cadences on a. The first A section ends on a closed G, followed by the short open rising phrase $X$, which leads to an open cadence on a (perfection 8). The repetition of the A material (perfections 9-14) returns to the closed G cadence, while the first phrase of the B section (perfections 15-20) ends on an open a, before the motet concludes (at perfection 24) with a return to the closed $\mathrm{G}$ cadence. This consistent alternation of closed and open sonorities is typical of a monophonic song, and the two tonal poles are very strongly articulated, because the upper voice nearly always cadences either on $\mathrm{G}$ or on a in unison with the tenor.

There is just one exception, at perfection 6, where the tenor-faithful to its chant quotation-weakens the arrival on the first $\mathrm{G}$ cadence by sounding the $\mathrm{c}$ a fourth above. The $\mathrm{A}$ section seems to set up the expectation of a strong cadence on $G$, and this is what happens at perfection 14 upon the repetition of the A material. At the first $\mathrm{G}$ cadence, however, in perfection 6, the tenor serves to undermine the sense of closure. Perhaps the motet creator wanted to avoid too strong a cadence on the closed pitch $G$ too soon, since the rather unconvincing musical cadence in perfections 5-6 is reflected in the text. This cadence falls in the middle of a poetic line (line 3) on the word "l'autrier," an unrhymed ending that occurs nowhere else in the motet. The motet's typical end rhyme, "-ais/-ois," is instead reserved for the stronger unison between motetus and tenor in perfection 8 , on the open a cadence at the end of the $\mathrm{X}$ insertion. ${ }^{18}$ The four-note portion of the tenor chant in question (perfections 5-8, marked by a dashed box in Example 3) returns in the B section at perfections 17-20. This tenor segment receives the same harmonic treatment the second time round, with the upper voice again sounding a $\mathrm{G}$ underneath the tenor $\mathrm{c}$ in perfection 18. On this second occasion, by contrast, the c-G chord falls in the middle of a phrase, rather than as part of a cadence, and its

${ }^{17}$ In perfections 21-22, the boxed tenor pitches c and G support an allusion to the A material in the upper voice, as they do in perfections 9-10.

${ }^{18}$ The copy of the motet in $\mathbf{W}_{\mathbf{2}}$ renders the "-ois" rhyme as "boais" and "Norrais" in lines 3 and 10, while the version in $\mathbf{N}$ maintains the standard "-ois" orthography ("bois" and "Norois") throughout. 
formal role is more straightforward, unambiguously leading toward the open cadence on a in perfection 20 .

The necessity of such small formal and tonal adjustments in "A grant joie" highlights the demands of marrying two different and relatively inflexible compositional techniques within a motet - a chant quotation and a song form. Nevertheless, this kind of combination is a skillful feat, and its success in "A grant joie" is arguably due in large part to the choice of the IUSTUS tenor, and furthermore to the extended twelve-note version of this melisma, with its additional closing pitches a-G. This extended version of the tenor enhances opportunities for repetition in an accompanying upper voice, as it allows the final four notes (pitches 9-12) of the IUSTUS melisma to be interchanged with its first four pitches. This is exploited in "A grant joie" to complement the reappearance of the A material at perfection 9, as well as to facilitate a brief allusion to the A material at the outset of the motet's closing phrase in perfections 21-22. Moreover, the extended version of the IUSTUS tenor increases the number of iterations of the pitches $\mathrm{G}$ and a, which can convincingly be set in opposition as tonal poles in a polyphonic composition, as they are so consistently in "A grant joie."

The only other extant motet on the IUSTUS tenor also adopts its twelve- rather than tennote version, and this motet also has an upper voice in a fixed, repetitive song form. ${ }^{19}$ "Ja n' ert nus" / IUSTUS is preserved uniquely in $\mathbf{N}(184 \mathrm{v})$ and has no extant related clausula (see Example 4). The motet is one of just thirteen motets in the thirteenth-century repertoire whose upper voices employ the eight-line rondeau form, ${ }^{20}$ with its framing two-line refrain (lines 1-2 and 7-8). ${ }^{21}$ Each line of the refrain has its own musical phrase (labeled A and B in Example 4) and the internal lines of the text are set to the same musical material-lines $3-5$ to the A phrase (line 4 also repeating the words of the first line of the refrain) and line 6 to the B phrase, producing the conventional rondeau form $\mathrm{ABaAabAB}$.

Example 4 "Ja n'ert nus" / IUSTUS, N, 184v

${ }^{19}$ The M 49 IUSTUS melisma shares its text but not its melody with another motet tenor drawn from "Alleluia. Iustus germinabit" (M 53).

${ }^{20}$ On the corpus of rondeau motets, see Everist, "Rondeau Motet."

${ }^{21}$ The refrain in "Ja n'ert nus" is no. 1011 (unique to this motet) in Nico van den Boogaard's Rondeaux et refrains (such numbers are hereafter marked "vdB"). In $\mathbf{N}$, the final presentation of the refrain is cued simply by its opening three words. On such cueing in rondeau motets, see Everist, “Rondeau Motet," 5-7. 
While the twelve pitches of the IUSTUS tenor are arranged in consistently repeating threenote patterns in the first rhythmic mode, the chant melody itself is not always repeated in full. Its first six pitches invariably correspond to the A phrase of the rondeau in the motetus and pitches 7-12 to the B phrase. However, whereas the IUSTUS chant is presented in full for text lines 1-2, 5-6, and 7-8 (statements I, III, and IV in Example 4), its first half is presented twice for lines 3-4 (statements II and IIa). ${ }^{22}$ In this case, the repetitive formal scheme of the rondeau is so strict that the creator of "Ja n'ert nus" cannot achieve this rondeau form in the upper voice without effectively "rondeau-izing" the accompanying chant tenor. Yet the IUSTUS tenor supports a very similar tonal profile to that of "A grant joie": the rondeau material consistently alternates between two cadence types a tone apart (though a fourth higher than those of "A grant joie" $\mathrm{e}^{\prime \prime}$, the A material always concluding on an open c cadence and the B material on a closed d cadence.

In both cases, the IUSTUS tenor was used to support the song-like tonal and formal profile of a corresponding motetus. The tenor HODIE offers an analogous example of a tenor for which there was no precedent of compositional reworking in the Magnus liber repertoire, but that was chosen for a vernacular motet with connections to monophonic song. ${ }^{23}$ In this case the motet does not employ a song-like structure, but rather invokes song traditions through the use of refrains, many of which are melodic quotations that are made possible by the simple, repetitive melodic profile and rhythmic arrangement of the HODIE tenor. HODIE resembles IUSTUS, not only in terms of its treatment and transmission within the Magnus liber, but also in its musical characteristics. It is of a similar length (thirteen notes) and likewise spans a limited range - $\mathrm{a}$ fifth, from $\mathrm{D}$ to $\mathrm{a}$ - with conjunct melodic motion and a concentrated repetition of two particular pitches, once again a tone apart (five iterations of $G$ and four of $F$ ).

The single surviving motet on HODIE, "Ja pour longue demouree," is recorded in MüA (4r) and Mo (267v-268r, where its tenor is imprecisely labeled DIES, the text corresponding to the slightly longer version of the HODIE melisma preserved earlier in the same M 2 Alleluia). Its

${ }^{22}$ The motet tenor in $\mathbf{N}$ is incomplete, lacking statement IV. Perfections $7-8$ of the tenor are also mistakenly copied a tone too high.

${ }^{23}$ Discounting the motet and its related clausula examined here, HODIE-with its ten texted identities (see note 000 above)—received twenty-one different polyphonic settings across the Magnus liber. All but one of these settings (the two-voice discant on VIDEO within the M 4 organum) simply state the tenor melisma once. Twelve of the discant settings are located within organa, eight are mini clausulae, and only one is a genuine independent clausula (see note 000 below). 
musical material is also uniquely preserved as an independent or substitute clausula in $\mathbf{F}$ (153r4), where the tenor is alternatively texted VENIMUS (M 10). ${ }^{24}$ "Venimus" represents the only extant independent clausula to treat this tenor melody, and-as argued below-is most likely a transcription of its related motet. ${ }^{25}$ A so-called cento motet, "Ja pour longue demouree" was created by joining together several independent refrain quotations (see Example 5). It consists of four separate sections, each constituting a different refrain. ${ }^{26}$ Textually, each refrain behaves as an independent unit with its own rhymes and syllable counts (see Table 3), while musically there is little correspondence of melodic motive across the refrain units and phrase lengths are generally irregular. ${ }^{27}$ As Mark Everist has emphasized, the refrains in many cento motets are unique, lacking known concordances that would prove their status as genuine quotations. ${ }^{28}$ This is the case in "Ja pour longue demouree": the words of the very generic second refrain-“ " $n$ 'oubli mie mes amours" in Mo, alternatively rendered as " $n$ 'oblie mie, bele amie" in MüA-constitute the kind of stock vocabulary that is widespread among motets and not consistently paired with corresponding musical material. Yet even if not all of its refrains are true quotations, the motet cultivates a patchwork cento character, and I have argued elsewhere that at least two of its four refrains are genuine quotations, identifying a new external concordance for the third refrain (vdB 310, whose melody has an internal ABA form, marked in Example 5). ${ }^{29}$

${ }^{24}$ The folio reference "153r-4" indicates the fourth clausula on folio $153 \mathrm{r}$.

${ }^{25} \mathbf{F}$ uniquely records an independent clausula on the tenor GLORIA (172r-4), whose tenor is taken from "Alleluia. Gloria et honore" (M 65a), a chant represented nowhere else in the Magnus liber but that shares the melody of the M 2/M 10 chant. The GLORIA tenor corresponds to the slightly longer version of the VENIMUS melody found at the outset of the Alleluia verse (in M 2 with the text DIES and in M 10 with the text VIDIMUS). The F clausula on GLORIA is a short single-statement setting whose tenor proceeds in ternary longs.

${ }^{26}$ Van den Boogaard identified just three different refrains within this short text, while Gennrich considered the final line of text also to represent a refrain: Boogaard, Rondeaux et refrains; Gennrich, Bibliographisches Verzeichnis.

${ }^{27}$ The translation in Table 3 is adapted from Tischler, Stakel, and Relihan, Montpellier Codex, 4:80.

${ }^{28}$ Everist, "Refrain Cento."

${ }^{29}$ Refrain 1, vdB 1018, survives as a refrain in text-only sources, but the motet's opening interval of a fourth is sufficiently unusual to suggest that the refrain is a musical quotation. I have identified a concordance for $\mathrm{vdB} 310$ (previously thought to be unique to "Ja pour longue 
Table 3 Text and translation of "Ja pour longue demouree" (Mo, 267v-268r)

Example 5 "Ja pour longue demouree" / DIES, Mo, 267v-268r

The status of this third refrain as a quotation in "Ja pour longue demouree" is confirmed by the fact that the HODIE tenor is altered to accommodate it. An extra a (marked by a box in Example 5), absent from both the established chant melody and the first tenor statement of the motet, is added in the second tenor statement at perfection 17. It is very unusual for two statements of the same chant melisma to differ from each other within a single composition. This extra a is mistakenly omitted in two of the piece's three manuscript sources (F and $\mathbf{M u ̈ A}$ ), even though it is required to make musical sense of the piece, whose tenor is otherwise one note too short. ${ }^{30}$ The introduction of an extra a in the second statement of the plainchant quotation facilitates its more consonant combination with the refrain quotation in the motetus, avoiding what would otherwise have been a stressed dissonant second between a tenor F and motetus $\mathrm{G}$ in perfection 20. Once again, this illustrates a dialogue between competing compositional parameters in the conception of this two-voice polyphony. Here the combination of two musical quotations-a plainchant melisma and a vernacular refrain melody-requires a small adjustment to one of them, in this case the tenor plainchant.

\section{Questions of Chronology and Style}

The claim that an interest in short and simple tenors in vernacular motets existed from an early date rests on the hypothesis that "A grant joie" / IUSTUS and "Ja pour longue demouree" / HODIE did not originate through the addition of texts to preexisting clausulae but that clausulae recorded in $\mathbf{F}$ rather represent textless transcriptions of these motets. In themselves, the musical characteristics of the discant clausula on IUSTUS (uniquely recorded within the "Alleluia. Letabitur iustus" organum in F) and the HODIE clausula (whose tenor is alternatively texted VENIMUS, also unique to F) are strongly indicative that they were conceived as motets, in conjunction with their accompanying vernacular texts. Of Gaël Saint-Cricq's corpus of sixteen motets in strict pedes cum cauda form, only two have clausula concordances,

demouree") within the motet "L'autrier quant me chevauchoie" / PRO [PATRIBUS]: Bradley, Polyphony in Medieval Paris, 135-37.

${ }^{30}$ The clausula in $\mathbf{F}$ also erroneously omits one of the repeated Gs in perfections 5-6 of the first tenor statement, while the position of tenor rests varies from source to source. 
both of which are apparently motet transcriptions. ${ }^{31}$ And in Friedrich Gennrich's corpus of nineteen refrain cento motets, "Ja pour longue demouree" is the only one to have a related clausula. ${ }^{32}$ The fact that the motet-related clausulae on IUSTUS and HODIE stand apart from the many other extant treatments of these tenor melismas within the Magnus liber seems to be a further indication of their different genesis. In the case of "Ja pour longue demouree," the liberties taken with its preexistent chant melisma attracted the attention of Wolf Frobenius, who argued that such tenor manipulation was uncharacteristic of clausulae and evidence of motet priority. ${ }^{33}$ Both Rudolf Flotzinger and Rebecca A. Baltzer had previously commented on the ambiguous ligation of the "Venimus" clausula duplum, further indication that this clausula was a sine littera transcription of a motet original. ${ }^{34}$ "A grant joie" presents a slightly less clear-cut case, not least because its musical material is lodged within a host organum in $\mathbf{F}$, rather than appearing as an independent clausula, this latter being a different generic category in which there is a more established and convincing precedent for motet transcription. ${ }^{35}$ Nevertheless, variants and notational features of the $\mathbf{F}$ discant on IUSTUS support its motet origin. ${ }^{36}$

Assuming the conventional generic progression from clausula to motet, however, Christopher Page argued that a pastourelle text associated with monophonic secular song was added to a liturgical model in "A grant joie" with expressly parodic intent. ${ }^{37}$ Page posited that the sacred origins of this vernacular motet would have been known to singers and listeners,

${ }^{31}$ Saint-Cricq, "New Link," 185-86.

${ }^{32}$ For Gennrich's corpus, see Everist, "Refrain Cento," 166.

${ }^{33}$ Frobenius, "Zum genetischen Verhältnis," 14.

${ }^{34}$ Flotzinger, Der Discantussatz, 68-70; Baltzer, "Notation, Rhythm, and Style," 1:353.

${ }^{35}$ Frobenius argued in favor of the priority of "A grant joie" over its related discant on stylistic grounds, problematically proposing that the "four-square structure" ("quadratische Struktur") of the motet represented a stylistically earlier incarnation of the musical material than the later, more "asymmetrical" ("asymmetrische") discant with its "limping rhythm" (“hinkender Rhythmus"): Frobenius, “Zum genetischen Verhältnis,” 20.

${ }^{36}$ See the discussion of notational irregularities in this discant and a transcription of it in Baltzer, "Notation, Rhythm, and Style," 1:350-53. The ambiguity of this discant notation is supported by its contrasting interpretations in modern editions: Baltzer's transcription differs (in perfections 57-58 and 65-66) from that of Everist (Les organa à deux voix, 129). Gordon Anderson offered an (unconvincing) alternative interpretation of this discant and motet in the third rhythmic mode: Anderson, “Newly Identified Tenor Chants," 163.

${ }^{37}$ Page, Discarding Images, 46-50. 
thereby invoking "the quality of 'turnabout' which Bakhtin describes as an essential element in the spirit of medieval festivity." ${ }^{38}$ The reversal of the clausula-motet chronology proposed here problematizes Page's interpretation. Yet Page's sense of the humor of this motet remains pertinent: the $\mathrm{X}$ insertion and the resulting disjunction between musical cadence and poetic rhyme would probably have caught the attention of a listener accustomed to a more conventional AAB form. The text unexpectedly breaks off before the expected denouement, and its final line suggests a double entendre, underlined by the curious downward swoop of a ninth (Example 3, perfection 22) on the word "roncin," a less elevated term for horse than the usual "cheval."

Another significant shared characteristic of the IUSTUS and HODIE motets might, however, seem initially to undermine the hypothesis that their origins were as motets rather than as clausulae. This is the rhythmic treatment of their tenor chants, a presentation of the pitches of the chant melisma in what Baltzer classifies as "ternary long simplices": the tenor simply proceeds in long notes of the same value that are not arranged into regular patterns. ${ }^{39}$ Indeed, the tenor transmission in both "A grant joie" and "Ja pour longue demouree" as regards the grouping of these longs through the placement of rests is inconsistent across the various sources. This is a style of tenor organization typically associated with the earliest layers of the organum and clausula repertoire in the Magnus liber, thought to precede the later, more complex arrangement of tenors into consistent patterns and in shorter note values that is usual in motets and evident in the rondeau motet "Ja n'ert nus" / IUSTUS. ${ }^{40}$ In contrast with large numbers of clausulae, only thirty-five motets in the entire thirteenth-century corpus employ unpatterned ternary-long tenors throughout. ${ }^{41}$ Yet twenty-six of them have vernacular texts, of which twenty contain refrains, five employ an AAB form in the upper voice, three are classified as rondeau motets, and two are refrain centos. ${ }^{42}$ This concentration of motets with direct links to vernacular song forms and refrain practices suggests that the uncomplicated tenor organization, once popular in the early layers of the Magnus liber repertoire, appealed also to motet creators:

${ }^{38}$ Ibid., 49.

${ }^{39}$ Baltzer, "Notation, Rhythm, and Style," 1:310-58.

${ }^{40}$ Anderson, for example, describes such unpatterned groups of longs or simplices as "a very archaic tenor disposition": Anderson, "Clausulae or Transcribed Motets," 127.

${ }^{41}$ See Baltzer, “Notation, Rhythm, and Style," 1:326-27, 356-58.

${ }^{42}$ For a complete list of motets with unpatterned ternary-long tenors, see Tischler, Style and Evolution, 1:122. Of the twenty motets containing phrases identified by Van den Boogaard as refrains, eight have refrains with surviving external concordances. 
its simplicity and flexibility permitted the employment of structural forms and refrains associated with vernacular song.

The presence of motets such as those on IUSTUS and HODIE transcribed as clausulae in a source as early as $\mathbf{F}$ belies two key presumptions, evident in statements by Klaus Hofmann and Everist respectively. First, that irregular tenor rhythmicizations and occasional alterations to preexistent chant melodies are "characteristics found primarily in motets of the late thirteenth century." ${ }^{43}$ And second, that "scattered attempts to incorporate chanson structures" appeared first in motets "ca. 1270." ${ }^{44} \mathrm{~F}$ encapsulates the possible simultaneity of different approaches to tenor melismas that were already current by the 1240s: it contains some genuinely "archaic" discant clausulae with unpatterned tenors; other independent clausulae and related Latin motets that offer multiple reworkings of elaborate chant melismas; and clausulae derived from vernacular motets that exploit the ability of short and malleable tenor melismas (usually passed over in the Magnus liber) to be combined with song-like upper voices. This combination, in "A grant joie" and "Ja pour longue demouree," of an "archaic" tenor arrangement with song-like characteristics linked to the "modern" genre of the vernacular motet further challenges chronological assumptions concerning stylistic features and generic categories.

\section{The OMNES Tenor and Its Heritage in the Magnus liber organi}

The tenor OMNES, drawn from the Christmas Gradual "Viderunt omnes," enjoyed a certain amount of attention in the creation of substitute clausulae and became-as shown in Table 1-the thirteenth-century's third most popular motet tenor. It embodies, to an even greater extent, the musical characteristics that made IUSTUS and HODIE amenable polyphonic foundations. Very similar in length, OMNES spans a fifth from D to a, and over half of its pitches are iterations of the melisma's final, $\mathrm{F}$ (see Example 1). These tenor characteristics are once again found in conjunction with frequent musical quotations in motetus and triplum voices as well as-in two motets-with repetitive formal structures. ${ }^{45}$ Yet unlike IUSTUS and HODIE, the short and simple OMNES tenor was repeatedly used as a motet foundation, and it reached the height of its popularity in a later layer of the thirteenth-century motet corpus, the repertoire of three-

${ }^{43}$ Hofmann, "Zur Entstehungs- und Frühgeschichte," 140: “Merkmale, die sich vorzugsweise in der Motette des späten 13. Jahrhunderts finden" (my translation).

${ }^{44}$ Everist, "Motets, French Tenors," 368.

45 The two motets with repetitive formal structures are "Ci mi tient" / "Haro" / OMNES, discussed in detail below, and "O viri israhelite" / OMNES, on which see note 000 below. 
voice vernacular double motets whose tenor melodies are invariably arranged in strict rhythmic patterns, preserved chiefly in the Montpellier Codex (Mo, the so-called old corpus of which was copied in the 1270s) and the Bamberg manuscript (Ba, dated to the late thirteenth century). ${ }^{46}$

In addition to the brevity of the OMNES melisma, its narrow range, and its pitch repetitions, part of the attraction of this tenor was probably also an established precedent for melodic flexibility in its polyphonic transmission. While thirteenth-century Parisian chant books agree on the version of the OMNES melisma presented in Example 1—with three iterations of the final pitch in the middle of the melisma-organa, clausulae, and motets additionally use a version with just two iterations of this pitch, as well as another version with four. A certain freedom in the handling of repeated pitches is relatively common in the conversion of chant melismas into rhythmicized polyphonic tenors. ${ }^{47}$ Yet in the case of the OMNES melisma, it is notable that this flexibility pertains across and within all of the types of the tenor's polyphonic instantiations. All three alternative versions of the OMNES melisma are found in the organa and clausulae of the Magnus liber repertoire, as they are in motets. ${ }^{48}$ Indeed, within the motet "De ma dame vient" / "Diex, comment porroie" / OMNES attributed to Adam de la Halle, the multiple statements of the OMNES melisma variously employ both the three- and the two-F version. ${ }^{49}$ There is not, therefore, an exclusive clausula or motet version of the OMNES tenor. The possibility for variant forms of the melisma evidently existed from an early stage of its treatment as a polyphonic foundation, and later thirteenth-century motet creators continued to be aware of and to exploit the conventions of earlier organa and clausulae.

${ }^{46}$ On Mo's "old corpus" and its date, see Bradley and Desmond, introduction to Bradley and Desmond, Montpellier Codex, 1. On Ba, see Norwood, "Evidence concerning the Provenance of the Bamberg Codex," and Pfändtner, "Zum Entstehungsraum."

${ }^{47}$ See the discussion of this phenomenon in the case of the AUREM TUAM tenor in Bradley, Polyphony in Medieval Paris, 21-26.

${ }^{48}$ Of the eleven OMNES settings in the Magnus liber, six have four Fs, three have three Fs, and two have two Fs.

49 The music of this motet survives in Mo (311r-314r) and Ha (35v-36r). The copy of the motet in Mo actually uses all three forms of the OMNES melisma, beginning with the four-F version. Since the presence of the extra F in Mo conflicts with the regular rhythmic pattern attained in the initial three-F tenor in $\mathbf{H a}$, it seems likely that the latter was the intended version. Adam's motet is exceptional in its combination of different versions of the OMNES tenor. I argue below that these varied forms of the tenor melisma are used to accommodate multiple quotations in the upper voices. 
Nevertheless, certain generic and chronologically contingent tendencies are evident in the handling of this tenor. Eleven different settings of the OMNES melisma are recorded within the Magnus liber repertoire. ${ }^{50}$ In all cases, the OMNES melisma is notated at a different pitch level from that shown in Example 1, whereby its final is not F but c (a fifth above), matching the conventional monophonic transmission of the melody in thirteenth-century chant books. ${ }^{51}$ Significantly, the four OMNES motets recorded in mid-thirteenth-century sources also use the c final, but the remaining nineteen-mainly later double motets—consistently adopt a transposed version of the melisma on $\mathrm{F}^{52}$ Treatment of the OMNES tenor in the Magnus liber is typically cursory: only two settings have more than one tenor statement, and these same two settings are also the only ones that arrange the pitches of the OMNES melisma in a rhythmic pattern. ${ }^{53}$ By contrast, motets on the OMNES tenor almost invariably feature multiple presentations of their short and rhythmically patterned tenor melody, and it is therefore unsurprising that just two of the twenty-three OMNES motets seem to have originated as clausulae to which motet texts were subsequently added..$^{54}$

${ }^{50}$ Four settings are passages of discant within complete host organa and seven are independent clausulae. One of the passages of discant is a four-voice setting in the "Viderunt omnes" organum attributed to Pérotin. All seven of the OMNES clausulae are recorded in F, three of which are additionally preserved in $\mathbf{W}_{\mathbf{1}}$. The final clausula in $\mathbf{F}$ (149r-2), whose tenor states the OMNES melisma nine times, is almost certainly a transcription of the French motet "En mon chant deslou" / OMNES (uniquely recorded in MüA) and is therefore excluded from further consideration among the "genuine" OMNES clausulae below.

${ }^{51}$ Variation in the pitch at which a chant melody is conventionally notated is fairly common, in both monophonic and polyphonic repertoires. The transposition of a melody by a fifth is especially frequent.

52 The four motets with c-final tenors are those in early and mid-thirteenth-century sources: the clausulae-derived "Homo cum mandato" in $\mathbf{W}_{2}$ and "Par pou li cuers" in $\mathbf{W}_{2}$ and MüA; "O viri israhelite" in $\mathbf{W}_{2}$; and "En mon chant deslou" in MüA, transcribed as a clausula in F.

53 These are the three-statement passage of discant preserved uniquely within an organum in F (100r) and the penultimate clausula in F (149r-1). As stated in note 000 above, I have not included the final clausula in F (149r-2, a vernacular motet transcription) in this figure.

${ }^{54}$ The only two extant OMNES motets with a single tenor statement are the two derived from clausulae, "Homo cum mandato" and "Par pou li cuers." 
It is in the motet repertoire that a clear preference for a particular melodic version of the OMNES tenor emerges, and this melodic version is strongly linked to the use of a particular rhythmic pattern. Fifteen of the twenty-three individual compositions use the three-F version of the OMNES tenor, the most common rhythmic arrangement of which is shown in Example $6 .{ }^{55}$ The ten pitches of the OMNES melisma are presented in a rhythmic pattern-a three-note group, followed by a two-note group — that is stated twice. The advantages of this rhythmic arrangement are clear: each complete statement of the rhythmic pattern begins and ends on $\mathrm{F}$, the final pitch (marked by boxes in Example 6), and the rhythmic groupings optimize the sense of melodic motion away from and returning to this tenor final. ${ }^{56}$ In particular, the two two-note groups (D-F and especially the ultimate G-F) offer ideal opportunities for cadence points on F. The exact rhythmicization shown in Example 6 is found within six different motets, as well as within a two-voice "Viderunt omnes" organum in $\mathbf{F}$ (here a fifth higher on c). ${ }^{57}$ Three further motets use this same tenor version and grouping but in slower-moving rhythmic values. ${ }^{5}$ And

55 This figure includes "De ma dame vient" / "Diex, comment porroie" / OMNES, discussed above, which employs both the three- and the two-F version of the OMNES tenor.

${ }^{56}$ The eleven-note four-F version of the OMNES tenor naturally lends itself less easily to the imposition of a consistent rhythmic pattern. Yet the nine-note two-F version of the melisma could simply have been divided into three three-note groupings in the fifth rhythmic mode, a highly conventional tenor pattern. This arrangement is found in none of the thirty-four extant OMNES compositions. On the contrary, many treatments of the two- and four-F OMNES tenors impose irregular rhythmicizations (see note 000 below), or manipulate the pitch content of the melisma, such that they produce effectively the same groupings of pitches as in the three-F tenor shown in Example 6.

${ }^{57}$ On the prevalence of this tenor rhythmicization, see also Everist, French Motets, 152-54. In addition to the five motets discussed by Everist, the same pattern also appears in the final two cursus of "Ami las" / "Doucement" / OMNES (unique to Mo). The only other rhythmically patterned treatment of the OMNES tenor in the Magnus liber (the clausula in F, 149r-1) uses the four-F version of the melisma. Despite this different version, the pitches (here transposed) are irregularly grouped with effectively the same result as in the three-F tenor shown in Example 6: F-G-F / D-F-F / F-F-a / G-F.

58 "Qui bien aime" / "Cuers qui dort" / OMNES (Mo and Ba) presents the 3/2/3/2 tenor pattern in ternary and duplex longs. In the motets "Ave caro splendida" / "Salve salus" / OMNES (unique to $\mathbf{H u}$ ) and "Salve laborancium" / "Celi luminarium" / OMNES (unique to Ba) the outline and arrangement of the $3 / 2 / 3 / 2$ grouping is maintained but the tenor proceeds in 
only one extant motet actively obscures the sense of the OMNES melisma as centered on F, the two halves of which open and close on this final pitch. ${ }^{59}$ Different rhythmicizations of the tenor naturally result in slightly different harmonic emphases: a slower rhythmic presentation of the OMNES melody, for instance, affords each individual pitch a greater harmonic weight. Yet surface variety in rhythmicizations, versions, and arrangements of the OMNES melisma notwithstanding, the fundamental compositional possibilities offered by this tenor-its emphasis on an F final opposed by a contrasting $\mathrm{G}$ tonality—are not substantively altered by its rhythmic arrangements, which in any case exhibit unusual consistency. ${ }^{60}$

Example 6 Typical motet rhythmicization of the OMNES tenor

\section{Musical Repetitions and Quotations in OMNES Motets}

The double motet "Ci m'i tient" / "Haro" / OMNES encapsulates the potential of the OMNES tenor, in its typical rhythmic arrangement, to support musical quotations and repetitions. This motet, preserved uniquely within the "old corpus" of Mo among a cluster of unica in the manuscript's fifth fascicle, is given in full as Example 7. The motetus voice has a repetitive structure in which the same musical and textual phrase frames two internal phrases that are themselves related. This Abb'A structure, with its opening and closing musico-textual refrain, caused the piece to be classified as a rondeau motet by Friedrich Gennrich, but Everist has queried attempts to strictly taxonomize this composition, whose kinship with virelais and motet enté forms has also been noted. ${ }^{61}$ The definition of the motet's framing phrase as a true refrain is also problematic, since surviving evidence does not permit the musical content of the

groups of three ternary longs $(3 / 3 / 3 / 3)$ owing to the repetition of pitches in the second and fourth tenor ordines (here marked in bold): F-G-F / D-D-F / F-F-a / G-G-F.

59 This motet is "Se je suis" / "Jolietement" / OMNES (unique to Mo), which groups the nine pitches of its two-F OMNES tenor as $2 / 7$. After the $3 / 2 / 3 / 2$ grouping, $5 / 5$ (5/4 or $5 / 6$ in the two- and four-F versions, respectively) and forms of 2/3/2/3 groupings are most prevalent.

${ }^{60}$ For example, the three- followed by two-note arrangement of the tenor gives particular emphasis to $\mathrm{G}$ as an alternative tonal pole on the melisma's penultimate note, while in the tenor's two- followed by three-note grouping $\mathrm{G}$ receives comparable rhythmic stress at the very outset of the melody, where it concludes the opening two-note group. In both cases, G receives rhythmic and harmonic prominence at important, but alternative, structural moments.

${ }^{61}$ See the summary and critique in Everist, French Motets, 106-7. 
A phrase to be established as a genuine quotation. "Haro, je n'i puis durer, ci m'i tient li maus d'amer!" (vdB 534) is found in this exact form only in the double motet under discussion. ${ }^{62}$ The formal function of the phrase, however, is indisputably refrain-like, as is its textual content, which evokes the conventional poetic topoi of a relatively extensive family of refrains that begin with the "Haro" (or "Hareu") exclamation, and also make reference to "li maus d'amer" (the pains of love) ${ }^{63}$

Example 7 "Ci m'i tient" / "Haro" / OMNES, Mo, 212v-213r

Musically, the remarkably neat fit between refrain and tenor statements (see Example 8) could suggest that the refrain melody was expressly tailored for the motet in question, to suit the typical rhythmic arrangement of the OMNES melisma. The presentation of the refrain matches a complete statement of the OMNES melisma in its most frequent rhythmic pattern. The refrain's melody is-conventionally for a refrain-in two distinct halves, each of which corresponds to a single iteration of the tenor's rhythmic pattern. Melodically, the phrases are a symmetrical pair: the first phrase traces a trajectory from c, up to $f$, and down to c again, while the second moves from c, down to F, and up to a concluding c. In the first statement of the refrain, both phrases open with the same $\mathrm{c}-\mathrm{b}$ progression (marked by a box in Example 8), closing with an inverse $b-c$ movement (marked by a dashed box). This refrain-like symmetry is facilitated by the melodic content of the OMNES melisma and its rhythmic arrangement, such that each half of the tenor pattern begins and ends on F.

Example 8 "Ci m'i tient" / "Haro" / OMNES, motetus and tenor, perfections 1-8

"Ci m'i tient" / "Haro" / OMNES stands out in the context of Gennrich's corpus of rondeau motets in its achievement of a strictly repetitive upper-voice structure without the need for drastic tenor manipulation or "rondeau-ization" of the kind evident in "Ja n'ert nus" /

${ }^{62}$ A slightly variant version of vdB 534-“Dieus, je n'i pux durer, ceu me font li mals d'ameir!"-is also found at the end of each verse of the chanson "Amors me font languir," uniquely preserved in Douce 308 (232r), an early fourteenth-century song manuscript containing no musical notation.

${ }^{63}$ See the examination of this family of refrains in Butterfield, "Repetition and Variation." 
IUSTUS. ${ }^{64}$ In fact, it is the only example of a rondeau motet that achieves both a literal melodic quotation and consistently regular rhythmicization of its tenor chant. ${ }^{65}$ This in itself is testament to the suitability of the OMNES tenor in its typical rhythmic arrangement-of its pitch content, structure, and duration-to supporting the conventional melodic and poetic form of a refrain. Even if vdB 534 does not represent a genuine musical quotation in "Ci m'i tient" / "Haro" / OMNES, this motet nevertheless achieves internal musical (and textual) quotations between its two upper voices. At the motet's opening, the triplum presents the second phrase of the refrain, transposed up a fourth (beginning on $\mathrm{f}$ rather than c, marked by boxes in Example 7), at the same time as the motetus presents the first phrase. The transposition of this refrain motive has several compositional advantages. Placing the triplum in a higher register distinct from that of the motetus, it emphasizes the motet's final, $\mathrm{f}$, at the octave above the tenor, facilitating a strong opening sonority characteristic of three-voice textures in this period, in which a fifth is framed within an octave. Although its melody has been transposed, the status of this opening triplum motive as a quotation is underlined by its text, which is drawn from the corresponding portion of the refrain. As a result, the motet begins with a simultaneous polyphonic presentation of the two halves of the refrain text and melody ("Haro, je n'i puis durer" in the motetus, "Ci m'i tient li maus d'amer" in the triplum) immediately followed by a repetition of the same combination of texts but with the voices exchanged ("ci m'i tient li max d'amer!" in the motetus, "haro, je n'i puis durer!" in the triplum). This textual exchange lacks an accompanying musical dimension in perfections 5-8 of the triplum, where there is no attempt to match the opening "Haro" text with a version of its accompanying motetus music. Instead, increasingly varied reiterations of the transposed version of the "ci m'i tient" phrase of the refrain serve as the basis of this and almost every subsequent triplum phrase (marked by open brackets in Example 7) ${ }^{66}$ Well served by the repetitious qualities of the OMNES tenor, this double motet is a repetitive tour de force, whose

${ }^{64}$ For Gennrich's corpus, see Everist, "Rondeau Motet," 2.

${ }^{65}$ Admittedly, the AABB form of another OMNES motet in Gennrich's rondeau motet corpus, "O viri israhelite" / OMNES, did depend on the manipulation of its tenor: the first five pitches of the three-F (here three-c) OMNES tenor (corresponding to the motetus's A material) are immediately repeated, and followed by a twofold statement of the remaining five pitches (corresponding to the motetus's B material).

${ }^{66}$ These repetitions seem occasionally to be prioritized over the harmonic relationship between motetus and triplum, since certain stressed dissonances occur between the two voices (see, for example, perfection 3). 
continued and varied reiteration of a short melodic idea in the triplum contrasts with and complements larger-scale and more literal formal repetitions in the motetus.

Ardis Butterfield has observed similar procedures of quotational exchange and repetition between the upper voices of the motet "Amoureusement mi tient" / "He amours" / OMNES. ${ }^{67}$ More generally, OMNES motets exhibit a high degree of interest in refrain quotation: five of the seventeen vernacular motets on this tenor feature intertextual refrains with externally attested musical concordances, while four further motets include refrains with extant text-only concordances. Quotational exchanges are also evident between different motet compositions on the OMNES tenor. As Jennifer Saltzstein has shown, in his motet "De ma dame vient" / "Diex, comment porroie" / OMNES Adam de la Halle alludes to the motet "Tant me fait" / "Tout li cuers" / OMNES, quoting the same refrain (vdB 1473) in identical combination with the OMNES tenor. $^{68}$ The triplum of the motet "Amoureusement mi tient" / "He amours" / OMNES also features an internal musical and textual quotation of the triplum incipit of another OMNES motet, "A diu commant" / "Por moi deduire" / "En non Diu" / OMNES. This kind of motet incipit quotation is relatively rare, and, as Anne Ibos-Augé has recently shown, is more prevalent in the concluding fascicles of the Montpellier Codex (fascicles 7 and 8, dated to the $1290 \mathrm{~s}$ or later) than in the older layers of the manuscript (from the 1270s). ${ }^{69}$ That such exchanges are particularly pronounced between motets on the OMNES tenor, in addition to the wellestablished conventions for rhythmic arrangements of this plainchant quotation in motets, suggests particular self-awareness among creators of OMNES motets-especially the vernacular double motets recorded in $\mathbf{M o}$ and $\mathbf{B a}$ - of a distinct and interrelated corpus.

${ }^{67}$ Butterfield, “'Enté,'” 79-85.

${ }^{68}$ On this shared quotation, see Saltzstein, The Refrain and the Rise of the Vernacular, 12729. This is the chronology tentatively proposed by Saltzstein, mainly on the grounds that Adam seems to have been familiar with motets in Mo: "Tant me fait" / "Tout li cuers" / OMNES is preserved in the "old corpus" of Mo (fascicle 5) and in Ba. This chronology is strengthened by the musical circumstances of Adam's motet, in which the OMNES melisma is presented twelve times, exceptionally in two different versions, and in three different rhythmicizations (four statements each of the three-, two-, and three-F versions respectively). These changes in tenor version within a single piece are themselves unusual, and it seems too much of a coincidence that the tenor version and rhythm should change for the final four tenor statements in such a way that its rhythmic pattern and the number of iterations of the pitch F match those accompanying the same refrain in "Tant me fait" / "Tout li cuers" / OMNES.

${ }^{69}$ Ibos-Augé, ". . . Que ne dit 'cief bien seans.'” 
OMNES and APTATUR: “Je ne chant" / "Talens" / APTATUR / OMNES

One further OMNES motet, "Se je suis" / "Jolietement" / OMNES, recorded uniquely in the final section (the eighth fascicle) of Mo, refers directly to another motet, this time on the tenor APTATUR (O 45). The Mo unicum quotes, at the close of its triplum voice, the text and music (transposed up a fifth) of the motetus incipit from a widely transmitted motet by Adam de la Halle, "Entre Adan et Hanikel” / "Chief bien seantz" / APTATUR. This quotational connection between an OMNES and an APTATUR motet-both of whose plainchant tenors were used by Adam, as discussed further below_chimes with the existence of a different kind of connection between these two tenor quotations: OMNES and APTATUR appear together in the exceptional four-voice motet with two tenors, "Je ne chant" / "Talens" / APTATUR / OMNES, preserved uniquely in $\mathbf{B a}$, the opening of which is transcribed in Example 9. ${ }^{70}$

Example 9 "Je ne chant" / "Talens" / APTATUR / OMNES, Ba, 57v-58r, perfections 1-12. A sound recording of this example is included in the online version of the Journal.

"Je ne chant" / "Talens" / APTATUR / OMNES constitutes the only known example of a thirteenth-century motet that presents two plainchant tenors simultaneously. Both tenor melodies are quoted literally and are arranged in rhythmic patterns, albeit slightly variable ones. Example 9 shows the first complete statement of the twenty-four-note APTATUR tenor, presented without a single alteration to its established melody. One statement of the APTATUR melody corresponds to two statements of the shorter OMNES tenor. OMNES appears here in the nine-note version that has just two central iterations of the pitch $\mathrm{F}$, and is subject to a minor melodic adjustment only in its second statement - the addition of an extra D (marked by a box in Example 9). The two statements of the OMNES tenor have different though internally consistent rhythmic patterns. Nine of the APTATUR tenor's twenty-four pitches are matched to the first statement of the OMNES tenor, while the second statement of the OMNES tenor supports the fast-moving presentation of the remaining fifteen APTATUR pitches, whose rhythmic arrangement begins and concludes in the same manner as that of the nine pitches that accompany the first statement of the OMNES tenor.

${ }^{70}$ Everist recently underlined differences between the four-part texture of this motet and four-voice motets in the fourteenth-century: Everist, “Machaut's Musical Heritage," 148-49. 
These two literally quoted tenor melodies make a successful harmonic and contrapuntal combination in "Je ne chant" / "Talens" / APTATUR / OMNES. In general, the two tenors move in contrary motion: only at the end of the APTATUR melody (perfections 9-12, marked by a dashed horizontal line between the two tenor staves) do the plainchant melodies shadow one another in unison. Similarly, save for a single unstressed dissonance between them-a second, sounding on the last breve of perfection 6 (marked by a dashed box) — the APTATUR and OMNES melodies make a strongly consonant combination, in which each perfection begins with the two tenors either in unison or at the interval of a fifth. Careful consideration of their respective rhythmicizations is key to the successful marrying of these two preexisting plainchant melodies. Yet the choice of the two tenors was crucial: APTATUR and OMNES are both centered tonally on F, closing with the same G-F cadence. ${ }^{71}$ Although APTATUR spans a much wider range than OMNES (from $\mathrm{C}$ to $\mathrm{c}$, above and below the melisma's final F), exactly two thirds of its sounding pitches belong to the F-a-C/c triad, and the very same proportion of the pitches of the OMNES melisma are either F or a. Recognition of these shared characteristics, which make the OMNES and APTATUR melodies so unusually compatible and ideally suited to polyphonic combination, was surely the compositional impetus for this sui generis and virtuosic four-voice motet.

\section{Accounting for APTATUR and the Semantic Appeal of Tenor Texts}

It is perhaps unsurprising that the combinatorial potential of OMNES and APTATUR was recognized, since both are among the most heavily reworked motet tenors of the thirteenth century. APTATUR served as the basis of thirteen different motets recorded exclusively in late thirteenth- or early fourteenth-century sources: Mo is the oldest manuscript to contain APTATUR motets, ${ }^{72}$ and they are heavily concentrated here and in Ba. ${ }^{73}$ As emphasized above,

${ }^{71}$ Both chant melodies are associated with the same two transpositions, one in which the melisma begins on $\mathrm{c}$, and another in which it begins on F. The two extant monophonic sources of the APTATUR melody begin alternatively on c and F. The APTATUR motet tenor can begin on c, $\mathrm{F}$, or even $\mathrm{G}$, but $\mathrm{F}$ is the most common starting pitch. Monophonic sources of the OMNES melody typically begin on c, while the OMNES motet tenor usually begins on F.

${ }^{72}$ Eight different APTATUR motets appear in Mo: one each in fascicles 2, 4, and 5; four in fascicle 7; and one in fascicle 8.

${ }^{73} \mathbf{B a}$ is the largest witness to the APTATUR motets, recording ten (out of thirteen). In addition to Mo and Ba, the following (mostly early fourteenth-century) manuscripts contain more than one APTATUR motet: Bes, Da, Hu, PsAr, Tu, Vorau. 
compositional interest in a tenor that had no previous history of polyphonic composition in the Magnus liber organi is exceptional in itself. ${ }^{74}$ Yet the ready adoption of APTATUR is more unprecedented still in that, as Jean-François Goudesenne has now established, the tenor stems from a plainchant responsory for a little-known Flemish saint, Saint Winoc of Bergues (a town now in northern France, very close to the Belgian border). ${ }^{75}$ In 1908, Paul Bayart discovered the APTATUR tenor melody and text in the responsory "Cum in hora" from the Office of Saint Winoc. ${ }^{76}$ Yet Pierre Aubry, rejecting the possibility that the APTATUR tenor could really originate in a responsory for such an obscure saint, continued to emphasize a connection that had been made before the Saint Winoc responsory was known—-between the APTATUR tenor and a similar melody accompanying the words PREBERE CELESTIA in the responsory "Beatus Nicholaus" for the much more widely venerated Saint Nicholas, with the implication that the APTATUR tenor melody was effectively a popular melodic formula used across a number of different chants. ${ }^{77}$ Goudesenne, in his 2000 article on the origins of APTATUR, likewise doubts that Parisian motet composers would deliberately have honored or invoked such a minor Flemish saint as Winoc, whose plainchant office survives in just two localized manuscript sources, one from Bergues and another from nearby Saint-Omer. ${ }^{78}$ Nevertheless, he shows conclusively that the Winoc responsory "Cum in hora" - probably the creation of a Parisian musician in the eleventh century, and compositionally independent of the Saint Nicholas responsory "Beatus Nicholaus"-must be the genuine source of the APTATUR tenor. The "Cum in hora" responsory offers the only exact musical match for the polyphonic tenor. It also represents the only instance in which the tenor melody (or any related version of it) is accompanied by the text APTATUR in a plainchant source. ${ }^{79}$

${ }^{74}$ A comparable tenor, though one much less widely adopted than APTATUR, is the melisma SOLEM, which appears in three motets, first recorded in Mo fascicles 7 and 8. Just twelve notes in length, SOLEM spans the interval of a fourth from $\mathrm{C}$ to $\mathrm{F}$ and principally oscillates between the pitches D (five iterations) and C (three iterations).

${ }^{75}$ Goudesenne, "L'Office de s. Winoc."

${ }^{76}$ Bayart, "Les anciens offices de saint."

${ }^{77}$ Aubry, Cent motets du XIIIe siècle, 3:72.

${ }^{78}$ See the discussion and transcription of these melodies in Goudesenne, "L'Office de s. Winoc," 283-84. The Saint-Omer antiphoner dates to the fifteenth century, revealing the longevity of the Saint Winoc Office, even if its transmission was limited and localized.

${ }^{79}$ Saltzstein states incorrectly that the word APTATUR is also present within the Office of Saint Nicholas: Saltzstein, “Rape and Repentance," 590-91. 
Perhaps understandably, given the lack of any convincing liturgical explanation for a Saint Winoc motet tenor, recent scholarship has continued to emphasize the more tenuous connection between APTATUR and Saint Nicholas. ${ }^{80}$ Significantly, at least one thirteenth-century motet composer seems to have connected the APTATUR tenor with Saint Nicholas too: the texts of the most widely transmitted APTATUR motet, "Psallat chorus" / "Eximie pater" / APTATUR, address Nicholas directly and by name. This suggests not only, as Goudesenne proposed, that thirteenth-century motet creators did not choose the APTATUR tenor for its connection to Winoc-whose name does not appear in any extant motets-but that some motet creators were actually ignorant of the tenor's liturgical origins. At least in the case of "Psallat chorus" / "Eximie pater" / APTATUR, the motet's creator either mistook the APTATUR melody for the similar passage on PREBERE CELESTIA in the "Beatus Nicholaus" responsory, or made the Saint Nicholas connection for the lack of any other frame of reference. ${ }^{81}$

Even for certain motet composers in the thirteenth century, then, the Saint Winoc tenor APTATUR was such an unusual choice that its liturgical heritage was irrelevant and even unrecognizable. This begs two questions. Why did such an obscure tenor become so popular? And more importantly, how was this little-known and localized plainchant melody absorbed into the polyphonic motet repertoire in the first place? The unexpected selection of APTATUR, as well as its widespread adoption, is explained to some extent by the musical and textual potential of the tenor itself. Musically, APTATUR, though longer and wider-ranging than OMNES, nonetheless offers very similar possibilities as a compositional foundation: the predominance of the pitches F, a, and C/c allows a closed F sonority to be contrasted with an open G sonority, supported by the tenor pitches $G$, b, and D.

APTATUR is typical, more generally, of tenors such as OMNES, PORTARE, and VERITATEM, which enjoyed considerably more popularity in late thirteenth-century motets than in the organa and clausulae of the Magnus liber.$^{82}$ Musically, all four of these tenors have the same F

${ }^{80}$ See ibid., 591. See also Clark, “'S'en dirai chançonete,'” 37n24.

${ }^{81}$ Since both upper-voice texts in "Psallat chorus" / "Eximie pater" / APTATUR close with the tenor word APTATUR, it is likely that the creator of these motet texts in praise of Nicholas presumed the APTATUR tenor to originate in a chant for this saint.

${ }^{82}$ Although VERITATEM appears twice as a tenor in Latin motets in F, it is more commonly found as the basis of French double motets. See the complete list of VERITATEM motets in Bradley, Polyphony in Medieval Paris, 47-48. There is just one extant mini clausula on VERITATEM. 
final (with the possibility of a c transposition), ${ }^{83}$ and they also share certain textual features. The word APTATUR, meaning "it is fitting" (or, more literally, "it is fitted [to it]"), was undoubtedly a key aspect of this tenor's appeal to motet creators, and its rich, multivalent, and sometimes ironic semantic potential has been demonstrated in poetic analyses of APTATUR motets by Sylvia Huot, Suzannah Clark, and Saltzstein. ${ }^{84}$ It seems to encapsulate the universal act of writing or "fitting together" the voices of a polyphonic motet, a meaning that operates also in the case of OMNES (all), another word that can be seen as describing the condition of polyphony. The Marian connotations of PORTARE (interchangeable with SUSTINERE) were richly exploited in late thirteenth-century motets, yet this word could also be interpreted as a description of the tenor itself, "carrying" a chant melody that is "sustained" at the bottom of the texture. ${ }^{85}$ And although VERITATEM (truth) is less applicable to acts of song making, its potential as a humorous and moral underpinning for upper-voice texts has been underlined by both Huot and Sean Curran. ${ }^{86}$ All four of these tenor words would seem to be more suitable and suggestive foundations for vernacular compositions than, for instance, the less abstract and more straightforwardly liturgical DOCEBIT (he will show), [IMMO]LATUS (sacrificed), or REGNAT (he reigns).

The musical and textual appeal of the APTATUR tenor notwithstanding, the question as to how motet composers first encountered it remains, and the localized aspect of this chant for a minor Flemish saint is difficult to account for within a model that has conventionally centered motet composition in Paris. Yet recent studies by Carol Symes and Saltzstein have illuminated medieval musical activity in northern France, particularly in Arras, home of the trouvère and composer of polyphony Adam de la Halle. ${ }^{87}$ Geographically, the neatest solution to the mystery

${ }^{83}$ As Pesce has emphasized, PORTARE has a slightly more complex tonal profile: Pesce, "Beyond Glossing," 28-37. The melisma commonly appears in motets at two pitch levels a fifth apart-starting on c and closing on G (as given in Example 1), or (less often) starting on F and closing on $\mathrm{C}$. This difference between the tenor's opening and closing pitches sets it apart from APTATUR, OMNES, and VERITATEM, but as in these other tenors, iterations of PORTARE's final (G or $\mathrm{C}$ ) and its corresponding opening pitch (c or F) constitute more than half of the melisma's pitch content.

${ }^{84}$ Huot, Allegorical Play, 32-35; Clark, "“S'en dirai chançonete,'” 37; Saltzstein, "Rape and Repentance," 591.

${ }^{85}$ See Pesce, "Beyond Glossing," 37-44.

${ }^{86}$ Huot, Allegorical Play, 99-106; Curran, "Feeling the Polemic."

${ }^{87}$ Symes, Common Stage; Saltzstein, The Refrain and the Rise of the Vernacular, 80-113 (on song culture in Arras), 114-48 (on Adam de la Halle). 
of the APTATUR tenor would be to propose Adam, comparatively close to Bergues in Artois, as its instigator in his very widely disseminated motet "Entre Adan et Hanikel" / "Chief bien seantz" / APTATUR. ${ }^{88}$ Only the Saint Nicholas APTATUR motet "Psallat chorus" / "Eximie" / APTATUR is more widely transmitted, but its misinterpretation or misrepresentation of the tenor source makes this motet an unlikely origin for the APTATUR tradition. ${ }^{89}$ In Adam's motet, on the other hand, as shown by Huot and Emma Dillon, the initial vowels of the APTATUR tenor assonate with and underline references to the composer's own name, whose sounds permeate the upper-voice texts. ${ }^{90}$ Furthermore, it could be argued that the choice of a northern French tenor (APTATUR) was a subtle musical evocation of the locale (Arras) explicitly depicted in its triplum text. It is even possible that the misconception that APTATUR was a tenor for Saint Nicholas arose because of the special status of this particular saint in Adam's life and legacy, as Symes has shown. ${ }^{91}$ Yet the most significant evidence against such an hypothesis is chronological: even though the copying dates of manuscripts cannot be straightforwardly equated with the age of their contents, it must be acknowledged that the earliest surviving manuscript source of "Entre Adan et Hanikel" / "Chief bien seantz" / APTATUR is fascicle 7 of Mo (dated to the 1290s), while three compositions on the APTATUR tenor are already contained within Mo's "old corpus," copied in the 1270s. Nevertheless, new evidence about Adam's approach to plainchant quotations, as well as a reconsideration of the chronological position of his works offered below, might support the tantalizing proposition that Adam was in some way responsible for the unlikely motet tenor APTATUR.

\section{Adam de la Halle's Three-Voice Rondeaux and Their Polyphonic Citation in Motets}

Five motets are securely attributed to Adam, since they appear within his "complete works" manuscript, $\mathbf{H a}$, a rare example of a thirteenth-century source with a section devoted to

${ }^{88}$ Adam's motet is found in Mo (fascicle 7), Ha, Bes, Ba, Tu, and Vorau.

${ }^{89}$ The Nicholas motet is found in Mo (fascicle 4), Ba, Da, Hu, ArsC, Pa11411, and Lo33327.

${ }^{90}$ Huot, Allegorical Play, 34; Dillon, Sense of Sound, 158-60.

${ }^{91}$ Symes, "Repeat Performances." Additionally or alternatively, Adam himself might have been attracted by the APTATUR melisma not only because of its northern French connotations, but also because its musical similarity to PREBERE CELESTIA offered the possibility to simultaneously evoke a chant for Saint Nicholas. 
a single author..$^{92}$ Adam uses the motet tenors OMNES (twice), APTATUR, IN SECULUM, and a unique polyphonic tenor with the text SUPER TE, for which a plainchant source has not previously been identified. ${ }^{93}$ I have now found an exact musical and textual match for Adam's SUPER TE tenor, accompanying the words SUPER TE ORTA EST within the responsory for Matins on the Feast of Epiphany, "Illuminare illuminare Iherusalem. Et ambulabunt." A transcription of this responsory as found in a mid-thirteenth-century Parisian breviary (Paris, Bibliothèque nationale de France, lat. 15613) is given as Example 10. ${ }^{94}$ The SUPER TE ORTA EST melisma occurs at the close of the respond, preceding the solo verse, precisely the moment in a plainchant responsory from which motet tenors are typically drawn. That Adam's tenor can now be proved to be a plainchant quotation is significant, not only because it shows that Adam apparently inaugurated a new plainchant tenor, but also because of the musical circumstances that motivated this inauguration.

Example 10 Responsory “Illuminare illuminare Iherusalem. Et ambulabunt," Paris, Bibliothèque nationale de France, lat. 15613, 108v

The motet "Aucun se sont loe" / "A Dieu commant" / SUPER TE presents, in the motetus voice, the refrain text and melody (vdB 12) found in the middle voice of Adam's own three-part polyphonic rondeau "A Dieu commant." ${ }^{95}$ In Adam's motetus, the A and B material of his rondeau refrain are presented in the split manner of the motet enté: the A material is placed at the beginning of the motetus and the B material at its conclusion, with new music "grafted" between them. Example 11 shows the refrain of Adam's rondeau as it is uniquely preserved in

${ }^{92}$ Adam's "complete works" section comprises folios 10r-68r. On Ha, see Everist, "Polyphonic Rondeau," 67-72.

${ }^{93}$ On the lack of an identified plainchant source for the SUPER TE tenor, see Saltzstein, The Refrain and the Rise of the Vernacular, 136. It is possible that the connection of the SUPER TE ORTA EST plainchant melisma with Adam's tenor was made-though never explicitly stated-by Tischler. In his edition of "Aucun se sont loe" / "A Dieu commant" / SUPER TE, Tischler supplies the editorial tenor text SUPER TE ORTA EST, though Mo has (erroneously) ET SUPER, and the only other copy of the motet, in Ha, gives merely SUPER TE. Tischler, Montpellier Codex, 3:8485 (no. 263).

${ }^{94}$ In Example 10, ligatures are indicated by slurs, conjuncturae by dashed slurs, and liquescents by joined pitches.

95 The refrain vdB 12 survives only in these two works by Adam. 
Ha, while Example 12 gives the corresponding portion of "Aucun se sont loe" / "A Dieu commant" / SUPER TE—the beginning and end of the motet—as recorded also in Ha. ${ }^{96}$ The middle voices of the two compositions, presenting the same refrain, are musically and textually identical, and-as previously noted by Friedrich Ludwig and Saltzstein-the two lowest voices are also undoubtedly related. ${ }^{97}$ There are only four differences of pitch between the lowest voice of the rondeau and the motet tenor and all are on unstressed breves (marked by boxes in Examples 11 and 12). There are two additional instances, also both on unstressed breves, in which a pitch sounding in the lowest voice of the rondeau corresponds to a rest in the motet tenor (marked by wavy boxes in Examples 11 and 12). Although the respective triplum voices are largely independent, their similar musical incipits and explicits (marked by dashed boxes in Examples 11 and 12) suggest that this aspect of the polyphonic complex was related too.

Example 11 Adam de la Halle, refrain of polyphonic rondeau "A Dieu commant," Ha, 33r

Example 12 Adam de la Halle, motet "Aucun se sont loe" / "A Dieu commant" / SUPER TE, Ha, $34 \mathrm{v}-35 \mathrm{r}$, perfections $1-6$ and $48-52$

That one of these compositions is modeled (polyphonically) on the other is therefore clear. ${ }^{98}$ But what is the citational direction: from rondeau to motet or from motet to rondeau? Conventionally, the priority of a monophonic rondeau as the origin of a refrain has generally been preferred, in view of both the inherent structural role of the refrain in this genre, and longestablished historiographical narratives that placed the origins of refrains in rondeaux and dance songs, rather than in motets. ${ }^{99}$ A rondeau priority is also most convincing in this polyphonic case, for several reasons. ${ }^{100}$ First, in the rondeau the refrain's B material is musically

${ }^{96}$ The only extant concordance for this motet is in Mo, fascicle 7, 288r-290r. Connections between Adam's motet output and the collection in Mo fascicle 7 are discussed further below. See also Everist, "Polyphonic Rondeau," 88-89.

${ }^{97}$ Ludwig, Repertorium 1:431; Saltzstein, The Refrain and the Rise of the Vernacular, 136.

98 That the refrain vdB 12, shared between motet and rondeau, was created by Adam is supported by the fact that it appears exclusively within his corpus and also by the autographical nature of its text; see Saltzstein, The Refrain and the Rise of the Vernacular, 135-48.

${ }^{99}$ For a summary (and critique) of these refrain origin narratives, see ibid., 10-16.

${ }^{100}$ Dissonance does not seem to be a useful chronological indicator here, since the first lowest voice variant results in a more consonant reading in the motet version, and the second 
identical to the beginning of the A material in all three voices, diverging only at the cadence. In the motet, however, the melodic relationship between the A and B sections of the motetus refrain is obscured by the fact that they appear in different harmonic and rhythmic tenor contexts. This change in the refrain's polyphonic context is demanded by the melodic sequence and rhythmic pattern of the tenor plainchant quotation. Second, had the motet been Adam's initial creation, while extra pitches would have had to be added to the lowest voice of the rondeau in order to support its syllabic text, there would have been no need to alter any pitches, which could simply have reproduced the melody of the motet tenor exactly. ${ }^{101}$ By contrast, the alteration of tenor pitches would have been required in a conversion from rondeau to motet, where Adam's choice of pitches was constrained by a plainchant quotation. In general, Adam's works in Ha seem to have been carefully cross-referenced, and refrains found in multiple compositions usually appear in exactly the same form (as in the case of "A Dieu commant"). ${ }^{102}$ It is especially likely, then, that had the direction of citation been from motet to rondeau, the lowest voice of Adam's rondeau would have replicated as exactly as possible the plainchant tenor of a parent motet.

A comparable case involving a motet by Adam offers contextual evidence for a citational direction from rondeau to motet. "De ma dame vient" / "Diex, comment porroie" / OMNES, in which Adam interchanges two different established versions of the OMNES tenor, contains the refrain (vdB 496) of another of Adam's polyphonic rondeaux, "Diex, comment porroie." ${ }^{103}$ In

produces a more dissonant reading in the motet version (that is avoided in the copy of the motet in Mo by a less exact quotation of the motetus refrain). In general, and as discussed further below, polyphonic rondeaux have a relatively high tolerance of second and seventh dissonances.

${ }^{101}$ With specific reference to this example, Butterfield observed that the "tenor of a rondeau is often a lightly expanded version of the corresponding motet": Butterfield, Poetry and Music, 282. But this does not account for the changes of pitch in the portions of the motet tenor that do not require expansion.

${ }^{102}$ On the consistency of refrain identities across Ha, see Everist, "Polyphonic Rondeau," 90. See also Butterfield, "Repetition and Variation," 13-15.

${ }^{103}$ Slight rhythmic and melodic variants in the refrain between Adam's rondeau (Ha, 34r) and motet additionally suggest accommodation to the polyphonic context of the motet. For example, on the word "qui" (perfection 61) both copies of the motet (in Mo, 311r-314r, and Ha, $35 \mathrm{v}-36 \mathrm{r}$ ) give $\mathrm{c}-\mathrm{d}$, rather than $\mathrm{d}$, which offers a stronger consonance with the underlying tenor F. 
this instance, only the rondeau's melody, its middle voice, appears in the motet context (transposed down a tone), ${ }^{104}$ and the refrain is split, though not quite in the conventional enté fashion: its A material occurs at the outset of the motetus, but the B material is presented not at the conclusion of this voice but in medias res. It is unlikely that Adam's rondeau was created by joining together such disparate parts of a motetus voice, and then creating accompanying outer voices. ${ }^{105}$ Furthermore, and as noted above, Adam quotes a different and widely disseminated refrain (vdB 1473) at the end of the motetus of "De ma dame vient" / "Diex, comment porroie" / OMNES, presenting it in exactly the same tenor context as in another OMNES motet. ${ }^{106}$ At the same time, the triplum voice itself quotes two well-known refrains, one of which-the opening "De ma dame" (vdB 477), found in a rondeau by Guillaume d'Amiens, another motet, and a chanson avec des refrains - is presented in similar enté fashion to the refrain "Diex, comment porroie": ${ }^{107}$ the opening of the triplum's refrain (vdB 477) sounds simultaneously with the motetus's refrain "Diex, comment porroie," while the second half of vdB 477 occurs later on, in the middle of the triplum voice. Adam's "De ma dame vient" / "Diex, comment porroie" / OMNES thus represents a patchwork of genuine quotations, from other motets and romances, as well as

${ }^{104}$ The rondeau's lowest voice and the motet tenor are too divergent to suggest a quotational relationship, but it is worth noting that-in terms of their general outline-the tenor pitches offered at the beginning of each perfection for the refrain's A material are similar: F-GF-F at the opening of the OMNES motet tenor, and (transposed down a tone) F-G-G-F in the lowest voice of Adam's rondeau.

${ }^{105} \mathrm{VdB} 496$ also appears, with music, in two copies of the romance Renart le nouvel, Renart C and Renart F. The melodies in the two copies are different. Furthermore, two different versions of the refrain are presented at different points in the romance in Renart $\mathrm{C}$. The first appearance of vdB 496 in Renart C resembles the refrain in Adam's polyphonic rondeau. It is possible, therefore, that Adam's rondeau itself borrowed (and perhaps altered musically) an existing refrain. Nevertheless, the closest connection between the different extant versions of vdB 496 is unquestionably that between Adam's rondeau and his motet, and there seems little doubt that one of these compositions quoted the refrain directly from the other. VdB 496 happens to be absent from the version of Renart le nouvel recorded in Ha itself.

${ }^{106}$ Adam himself additionally quotes the melody of this refrain in his "Je de la feuilleee." On the status of "Tant me fait" / "Tout li cuers" / OMNES as the model for "De ma dame vient" / "Diex, comment porroie" / OMNES, see note 000 above.

${ }^{107}$ The second refrain quoted internally in the triplum is $\mathrm{vdB} 765$, which has three independent surviving text-only concordances. 
from one of his polyphonic rondeaux. Although the rondeau citation does not preserve its polyphonic context in this instance-arguably made impossible, at least at the motet's outset, by its combination with another refrain quotation in the triplum - the motetus's concluding refrain does maintain the tenor context of its appearance in another OMNES motet. This confirms that Adam took the harmonic context of refrain quotations into consideration, perhaps-as Saltzstein has suggested-in order to increase their audibility. ${ }^{108}$ And all in all, "De ma dame vient" / "Diex, comment porroie" / OMNES is testament to Adam's facility and compositional interest in quotation, of refrains and tenor plainchants alike, and in the musical combination of such quotations.

In addition to musical and contextual evidence, the selection of the long unidentified motet tenor SUPER TE-drawn from a plainchant melody that appears nowhere in the polyphonic repertoire of the Magnus liber or in any other extant motet-itself requires some justification. The tenor was unfamiliar to the scribe of the Montpellier Codex's seventh fascicle, who labeled the tenor of Adam's motet ET SUPER, the name of a different chant melody used in four other motets in Mo. This mislabeling may well have been the scribe's own "correction." Like SUPER TE, the ET SUPER tenor melody begins on F, the melody's final or home pitch. Given the similarity of the two tenor labels, the scribe plausibly took the formulation SUPER TE to be an error, having encountered it nowhere else in the manuscript. It seems all the less likely that Adam would scrupulously preserve, as a rondeau tenor, the contour of an unusual plainchant quotation, evidently unrecognizable to the thirteenth-century scribe of Mo. It is more plausible that he instead deliberately sought out a plainchant melisma that offered as similar as possible a harmonic foundation to the lowest voice of his existing rondeau, and - in order to find onewas forced to choose from outside the range of established polyphonic tenors.

The motet "Aucun se sont loe" / "A Dieu commant" / SUPER TE would therefore constitute the first known instance in which a plainchant melody-never previously (or subsequently) used as a polyphonic tenor-was chosen to replace and to resemble as closely as possible the lowest voice of a preexisting polyphonic rondeau. The choice of the SUPER TE melisma was a good solution, and it was quoted without a single melodic alteration and arranged in a consistent rhythmic pattern. It is reasonable to expect that a well-educated and musical cleric such as Adam would have had considerable familiarity with liturgical plainchant melodies and was thus able to recall a melisma that, like his rondeau tenor, predominantly

${ }^{108}$ Saltzstein has also proposed that the noticeability of quotations is increased by the additional quotation of, or allusion to, a polyphonic context: Saltzstein, The Refrain and the Rise of the Vernacular, 137. 
circled around the pitches F, G, and a. ${ }^{109}$ The motet "De ma dame vient" / "Diex, comment porroie" / OMNES reveals Adam's keen awareness of the conventions for plainchant quotation in polyphony: it is the only surviving motet to exploit different established versions of the OMNES tenor within a single piece, using two of its possible incarnations (with three and two iterations of the pitch F) to facilitate the motet's myriad upper-voice quotations.

The lowest voice of Adam's rondeau "A Dieu commant" exemplifies the essential characteristics observed in all of the motet tenors examined above. A closed sonority, F, is pitted against an open G. The rondeau's A section closes on the open G sonority, the sonority that also prepares the eventual closed cadence on $\mathrm{F}$ at the end of the B section. The lowest-voice pitch a is used in a similar manner to F: it supports the pitches $\mathrm{c}$ and e in the upper voices, both of which are also used in conjunction with $\mathrm{F}$ (despite the resulting dissonance in the case of e). By contrast, the alternative lowest-voice sonority, $G$, is usually reserved to support the pitches b and $\mathrm{d}$. By comparison with the equivalent motet tenor, the harmonic foundation provided by the lowest voice of the rondeau moves at a slower rate, the tenor consistently sustaining the same pitch for the duration of a perfection. ${ }^{110}$ In addition, the rondeau consistently alternates strongly consonant sonorities at the beginning of each perfection with weaker consonances, or more often genuine dissonances, on the final breve of each perfection. ${ }^{111}$ In the motet, by contrast, the idiom is generally more consonant, mainly thanks to the choice of triplum pitches (which avoid the rondeau's harmonic combination of e and F). The motet's harmonic rhythm is faster, because the tenor changes its pitch more frequently, as required by the quotation of the SUPER TE melody. ${ }^{12}$ Analysis of these two examples usefully illuminates the relationship between the three-voice genres of the polyphonic rondeau and the polytextual motet. It has underlined a fundamentally shared compositional basis-both genres are underpinned by opposing harmonic poles a tone apart—while illustrating crucial stylistic differences, which reflect the generally less complex and esoteric aesthetic of the rondeau, with its slower-moving harmonic rhythm, greater tolerance for dissonance and parallel motion, and —of course—its presentation of a single text in a homorhythmic texture.

${ }^{109}$ On Adam's clerical status and his academic title "maistre," see ibid., 117-23.

110 The single exception is the tenor's decorative movement at the end of perfection 4 .

111 The single exception is again at the end of perfection 4 .

112 The lowest voice of "A Dieu commant" is slower moving and features more repetition of its individual pitches than those of most of Adam's other rondeaux. This argues against the proposition that the lowest voices of his rondeaux were necessarily simplifications of their motet tenor equivalents. 
Such differences between the idioms of motets and polyphonic rondeaux could suggest that the latter belonged to a less formalized, even an extemporized genre, in which tenor and triplum voices were often fitted fairly freely around a rondeau melody in the middle voice. ${ }^{113}$ The paucity of written musical records of polyphonic rondeaux-in itself perhaps suggesting an oral tradition-limits understandings of the genre. It could therefore seem problematic to insist (as above) on the very literal "citation" of the lowest voice of a polyphonic rondeau if this nonmelodic voice was, in fact, subject to a high degree of variation. Musical concordances external to Adam's complete works manuscript, $\mathbf{H a}$, exist for only four of his sixteen polyphonic rondeaux. The third leaf of the composite manuscript $\mathbf{C a B}$, made up of various thirteenth- and fourteenth-century binding fragments, presents the four pieces that open the collection of Adam's rondeaux in Ha. Significantly, these rondeaux are in exactly the same order in the two sources, and three of the rondeaux in $\mathrm{CaB}$ match the musical texts in $\mathrm{Ha}$ almost note for note. Both of these circumstances confirm that, even if conceived and / or circulated orally, the rondeaux additionally had an established written transmission that was largely stable. The concept of recognizable polyphonic "citations" from rondeaux in motets is therefore valid.

Yet the two versions of the fourth of these compositions shared between CaB and Ha, "Li dous regars," offer a different perspective, and one with potentially significant ramifications for understandings of different types of practices within the generic context of polyphonic rondeaux. As Everist observed, "the middle voice in both versions is essentially unchanged, and, although the melodic profiles of the outer voices are modified, the overall contrapuntal structure is identical." ${ }^{114}$ Differences in the details of the outer voices vary, but within stable parameters: if the pitch of the triplum in $\mathbf{C a B}$ differs from that in Ha then it is usually at the transposition of the fourth, while pitches in the lowest voice vary usually by the interval of a fifth or a third. "Li dous regars" is one of just two of Adam's rondeaux in which all three voices cross and overlap in range, thereby increasing the possibility that tenor and triplum might interchange their respective pitches. ${ }^{115}$ Conversely, voice crossing is more limited-in one case even nonexistent-in the three remaining rondeaux with concordances in $\mathbf{C a B}$, and this may

113 The middle voice of a polyphonic rondeau can be considered its melody; see Everist, "Polyphonic Rondeau," 84-85. It is always the middle voices of polyphonic rondeaux that have concordances with monophonic rondeaux in other sources, and quotations of refrain melodies from polyphonic rondeaux invariably match their middle voices.

${ }^{114}$ Ibid., 63. See also the contrapuntal summary in Everist's Example 1.

${ }^{115}$ On voice crossing in Adam's rondeaux, see ibid., 93. I draw on the data in Everist's Table 6 for tessitura and voice crossing in Adam's rondeaux corpus. 
contribute to their stability. While seven of Adam's sixteen rondeaux feature voice crossing between their lowest voice and the rondeau melody, none of the four polyphonic rondeaux with concordances in motets is in this category. This could indicate sensitivity in the selection of rondeaux quotations to the typical independence of tenor and motetus voices in the motet genre, and perhaps also a preference for quoting rondeaux with more stable harmonic identities. Alternatively, it could suggest that there were two types of polyphonic rondeaux: while some were based around a middle-voice melody, others were conceived as a three-voice complex without a central melody. The former type was either preferred for monophonic transmission and motet quotation, or it represented a later polyphonic expansion of existing song material, rather than a composition that was polyphonically conceived from the outset.

\section{A Curious Motet-Rondeau Hybrid: “Dame bele" / "Fi, mari" / NUS N'IERT JA JOLIS}

The circumstances of Adam's "Aucun se sont loe" / "A Dieu commant" / SUPER TE might resolve the compositional riddle posed by another motet with connections to rondeaux, "Dame bele" / "Fi, mari" / NUS N'IERT JA JOLIS. This motet is preserved in the seventh fascicle of Mo and in the fragmentary source Reg, but it is absent from Ha and is therefore nowhere attributed to Adam de la Halle. Like that of Adam's "Aucun se sont loe" / "A Dieu commant" / SUPER TE, the opening of "Dame bele" / "Fi, mari" / NUS N'IERT JA JOLIS closely resembles—in tenor, motetus, and triplum voices-the music of a polyphonic rondeau by Adam, "Fi, mari," whose accompanying refrain text is present in the motetus. ${ }^{116}$ In the case of "Aucun se sont loe" / "A Dieu commant" / SUPER TE, it was remarkable that a tenor plainchant quotation should closely resemble the lowest voice of Adam's rondeau "A Dieu commant." In "Dame bele" / "Fi, mari" / NUS N'IERT JA JOLIS, the motet tenor-similarly related to the lowest voice of Adam's rondeau "Fi, mari" - also appears to be a quotation, but this time of the text and (presumably) the melody of another vernacular rondeau, “Nus n'iert ja jolis," rather than of a

116 The only remaining instance of refrain material shared between one of Adam's polyphonic rondeaux and a motet concerns the rondeau "He, Diex, quant verrai" (vdB 823) and two motets extant in Mo (fascicle 7): "Bien met amours" / "Dame, alegies ma grevance" / A PARIS and "Theoteca Virgo geratica" / "Las, pour quoi” / QUI PRANDOIT. VdB 823 is quoted internally near the end of the triplum in the former and at the close of the motetus in the latter, appearing in both cases above tenors that are very similar to (but do not match exactly) the lowest voice of Adam's rondeau. This could indicate that the vernacular song quotations in the motet tenors were selected to recall the lowest voice of Adam's rondeau. 
liturgical plainchant. Outside the tenor voice of "Dame bele" / "Fi, mari" / NUS N'IERT JA JOLIS, this rondeau survives uniquely in the manuscript $\mathbf{P a B}$, a source whose layout was designed to accommodate the music of three-voice rondeaux but in which musical notation was never entered. ${ }^{117} \mathbf{P a B}$ records the complete text of the polyphonic rondeau "Nus n'iert ja jolis." ${ }^{118}$ But it is impossible to establish whether or not the tenor in "Dame bele" / "Fi, mari" / NUS N'IERT JA JOLIS also quotes the music of the middle voice of "Nus n'iert ja jolis" that is missing in PaB.

Observing these quotational interrelationships in his 1996 article on the polyphonic rondeau ca. 1300, Everist emphasized their "complex implications" for understandings of compositional processes in motets and rondeaux. ${ }^{119}$ He offered three hypothetical explanations. First, that the rondeau "Nus n'iert ja jolis" served as the basis of the motet "Dame bele" / "Fi, mari" / NUS N'IERT JA JOLIS, which was then the model for Adam's own rondeau "Fi, mari." Second, that the polyphonic rondeaux "Nus n'iert ja jolis" and "Fi, mari" were musically identical and the motet "Dame bele" / "Fi, mari" / NUS N'IERT JA JOLIS took the tenor of the former and the upper voices of the latter. And third, that Adam's rondeau "Fi, mari" was the model for the motet "Dame bele" / "Fi, mari" / NUS N'IERT JA JOLIS, in which a new text for the lowest voice of the "Fi, mari" rondeau was created. This newly texted motet tenor then circulated separately as the melody of a different polyphonic rondeau, "Nus n'iert ja jolis." Regarding the second of these possibilities as the least likely, Everist underlined the fact that each one of them "necessarily presupposes a compositional procedure unknown elsewhere in this repertory." 120

In the light of "Aucun se sont loe" / "A Dieu commant" / SUPER TE, an alternative explanation, and one that does have a compositional precedent, emerges: that the creator of "Dame bele" / "Fi, mari" / NUS N'IERT JA JOLIS modeled his motet polyphonically on Adam's rondeau "Fi, mari," and chose a suitable tenor quotation-the melody of the rondeau "Nus

${ }^{117}$ See PaB, 79v. On PaB, see Everist, "Polyphonic Rondeau," 61-69. Everist considers PaB to be "contemporary" with $\mathrm{Ha}(61)$.

${ }^{118}$ In the motet version in Mo only the text of the rondeau refrain is given in the tenor, even though the tenor presents the rondeau melody in its entirety. This is conventional and economical in polyphonic sources, as it allows the untexted continuation of the tenor to be notated in ligatures. The copy of "Dame bele" / "Fi, mari" / NUS N'IERT JA JOLIS in Reg (1r) preserves only the ending of the tenor, and (as in Mo) these pitches are not underlaid with the rondeau text.

${ }^{119}$ Everist, "Polyphonic Rondeau," 85-86, here 85.

${ }^{120}$ Ibid., 85. 
n'iert ja jolis" - to replicate the melodic contour of the lowest voice of Adam's rondeau. Example 13 presents Adam's rondeau "Fi, mari" for comparison with the motet "Dame bele" / "Fi, mari" / NUS N'IERT JA JOLIS, shown in Example 14 (variants in the lowest voices that result in harmonic differences are marked by boxes). As in the case of the rondeau "A Dieu commant" and "Aucun se sont loe" / "A Dieu commant" / SUPER TE, the relationship between the triplum voices in "Fi mari" and "Dame bele" / "Fi, mari" / NUS N'IERT JA JOLIS is the most distant, but they have the same musical incipit, whose continuation also shares details of melodic contour and rhythmic outline, as well as similar explicits (marked by dashed boxes in Example 13). The middle voices of the two compositions are, in their presentation of the refrain vdB 746, musically and textually identical. ${ }^{121}$ And the two lowest voices begin identically before diverging slightly: the motet tenor has a different pitch at the end of perfection 3 , and it is shorter than the lowest voice of Adam's rondeau, effecting the same final G-F cadence progression but in a different rhythm at an earlier point in the refrain melody. ${ }^{122}$

Example 13 Adam de la Halle, polyphonic rondeau "Fi, mari," Ha, 33r-v

Example 14 Motet “Dame bele" / "Fi, mari” / NUS N'IERT JA JOLIS, Mo (fascicle 7), 300v-301r

Though slight, such musical divergences support the argument that the motet did not simply reproduce, and then retext, the lowest voice of Adam's "Fi, mari." The status of the NUS $N^{\prime}$ IERT JA JOLIS tenor as a quotation — of another genuine rondeau text and melody - is corroborated also by the scrupulous preservation and structural importance of its rondeau form (indicated by letters in Example 14), presented in full in the motet. Furthermore, the first return of the A music of the tenor's rondeau with its accompanying refrain text- "nus n'iert ja jolis" (tenor text line 4, at perfections 9-11) -is matched by a reprise of the A music of the motetus's

${ }^{121}$ Like Adam's rondeau refrain "Diex, comment porroie" (vdB 496, discussed in note 000 above), vdB 746 also appears, with music, in two copies of Renart le nouvel, this time in Renart F and in Ha. As is typical of refrains that appear on multiple occasions in $\mathbf{H a}$, the version of the refrain in Renart le nouvel matches exactly that in the rondeau by Adam found earlier in the same manuscript. Renart F, however, presents a different refrain melody.

${ }^{122}$ While it could be argued that the tenor was altered to create the overlapping phrase structure characteristic of motets, such independence of motetus and tenor phrasing was not enforced in "Aucun se sont loe" / "A Dieu commant" / SUPER TE, where these voices cadence together at the presentation of the rondeau refrain's A material. 
rondeau refrain (marked by a dashed box in Example 14). The motetus's refrain melody is accompanied by a line of text-line 4, "qui me sert et nuit et jour" — that also appears later in Adam's "Fi, mari" rondeau (as line 5, accompanying the same A music and marked by a dashed box in Example 13). The relationship between "Dame bele" / "Fi, mari" / NUS N'IERT JA JOLIS and Adam's "Fi, mari" rondeau thus extends beyond their shared refrain. ${ }^{123}$ That an additional textual connection between the two compositions occurs at a structurally significant moment in "Dame bele" / "Fi, mari" / NUS N'IERT JA JOLIS, motivated by the independent rondeau form of the tenor, arguably underlines the status of the line "qui me sert et nuit et jour" as a citation in the motet. It is harder to explain why Adam would borrow just one additional line of a motet text for the fifth line of his rondeau. ${ }^{124}$

The proposition that "Dame bele" / "Fi, mari" / NUS N'IERT JA JOLIS achieves two simultaneous quotations - of the rondeau "Nus n'iert ja jolis" in its tenor, and of Adam de la Halle's rondeau refrain "Fi, mari" and its surrounding polyphonic voices-unsettles established scholarly presumptions about quotation, as well as about chronological relationships and directions of influence between polyphonic rondeaux and motets in the late thirteenth century. None of Everist's hypothetical explanations for the genesis of this motet considered the possibility of a double quotation. Yet as this article has argued, such double quotations are part of the compositional and aesthetic currency of the thirteenth-century motet repertoire, found in its earliest and latest witnesses: they include, as we have seen, the combination of a plainchant tenor and a predetermined song form or a preexisting refrain melody, and — uniquely in "Je ne chant" / "Talens" / APTATUR / OMNES—-the combination of two plainchant tenors. Triple and even quadruple quotations are also encountered in motets that achieve the quotation of two or three preexistent refrain melodies above a plainchant tenor. In the context of such quotational feats, it is likely that motet composers were also capable of selecting either a plainchant tenor or a vernacular song melody that resembled the lowest voice of a polyphonic rondeau. If anything, the compositional task of finding a chant melisma, and perhaps especially a vernacular song,

${ }^{123}$ Ludwig noted the appearance of an additional line of text from Adam's rondeau in "Dame bele" / "Fi, mari" / NUS N'IERT JA JOLIS in conjunction with the beginning of the refrain melody: Ludwig, Repertorium, 1:436. Subsequent discussions of the motet have not commented on this feature.

${ }^{124}$ Syllable count was not the determining factor, since lines 3 and 6 of the motetus text are also of the seven syllables required for the rondeau's A material. It would be surprising had Adam selected only lines 1, 2, and 4 of the motetus, rather than simply appropriating lines 1-4 in their entirety. 
that turned around the pitches F, G, and a and could stand in for the lowest voice of a rondeau would seem to be an easier one than combining multiple plainchant tenors or refrains.

Moreover, this kind of quotational substitution seems to be a natural corollary of the more usual and established combinatorial procedures.

Quotations of monophonic song have an established precedent in the earliest layers of vernacular motets. Given that polyphonic vernacular song traditions became increasingly prevalent in the later thirteenth century, it would not be surprising if motet quotations came to encompass the polyphonic dimension also. Scholarly discussions of these isolated known cases of polyphonic concordances between motets and rondeaux have, however, tended implicitly to favor the reverse relationship: that Adam's polyphonic rondeaux derived from his motets. In an attempt to challenge older conceptualizations of Adam's polyphonic rondeaux as popular dance-songs, Butterfield suggested that these compositions should be viewed "as a response to experiments with refrains in polyphony in the genre of the motet." ${ }^{125}$ Similarly, though perhaps in deference to the motet's more established status as a polyphonic genre, Robert Falck tentatively posited the polyphonic "interdependence" between rondeau and motet in "Dame bele" / "Fi, mari" / NUS N'IERT JA JOLIS as an indication that Adam's rondeau may have been based on the motet. ${ }^{126}$ Although Everist deliberately left open chronological questions about the status of "A Dieu commant" and "Aucun se sont loe" / "A Dieu commant" / SUPER TE, he nonetheless preferred, more generally, to ascribe priority to the motets in fascicle 7 of $\mathbf{M o -}$ proposing that Adam was familiar with this repertoire-rather than to Adam's rondeaux. ${ }^{127}$

In fact, there exists stronger evidence to support the reverse scenario- that the creators of motets in Mo fascicle 7 were already familiar with Adam's output. Fascicle 7 of Mo is dated to the 1290s, probably after the death of Adam (thought to have been born between 1245 and 1250), and certainly after he had already experienced life in Paris and was well established as a

${ }^{125}$ Butterfield, Poetry and Music, 283.

${ }^{126}$ Falck, "Adam de la Halle." See also Symes, “'School of Arras.'” I thank Professor Symes for sharing this material with me prior to publication.

${ }^{127}$ Everist states that it is "perhaps more likely, and easier to prove" that Adam was familiar with the repertoire of Mo fascicle 7, than that the composers of the motets in Mo 7 knew Adam's rondeaux: Everist, “Polyphonic Rondeau,” 88-89. While Saltzstein deliberately avoids chronological judgment (The Refrain and the Rise of the Vernacular, 127-29, 135-39, 14147), she is generally sympathetic to Everist's proposed precedence for the repertoire of Mo 7 (129). 
composer. ${ }^{128}$ Mo fascicle 7 is roughly contemporary with Adam's "complete works" manuscript, $\mathbf{H a}$, which seems to have been compiled posthumously in the late $1280 \mathrm{~s} .{ }^{129}$ The date of copying for Mo fascicle 7 allows sufficient time for its motet creators to have engaged with and absorbed Adam's compositional output and thus meaningfully to invoke this output through citation. The compilers of fascicle 7 undoubtedly knew and valued Adam's work, since they included three of the five motets that appear under his authorship in $\mathbf{H a} .{ }^{130} \mathrm{I}$ have argued above that two of these fascicle 7 motets ("Aucun se sont loe" / "A Dieu commant" / SUPER TE and "De ma dame vient" / "Diex, comment porroie" / OMNES) contain self-citations from Adam's polyphonic rondeaux. In these cases, Adam's polyphonic rondeaux undeniably predate the copying and contents of fascicle 7, and the appearance of material from Adam's rondeaux within motets already had the status of a citation in the musical repertoire to which fascicle 7 is a written witness.

Six motets absent from the group attributed to Adam in Ha are known to contain refrains or rondeau melodies elsewhere associated with him. All six motets are recorded in Mo: five in the seventh fascicle, and one in the related collection in the later eighth fascicle. ${ }^{131}$ Only two other extant manuscripts record two or more of this group of compositions; ${ }^{132}$ two of these six motets are unique to $\mathbf{M o}{ }^{133}$ and at least half of them appear to cite existing compositions by Adam, rather than to be the models for Adam's works. ${ }^{134}$ Given Adam's penchant for self-

${ }^{128}$ On the dating of Mo fascicle 7, see Bradley and Desmond, introduction to Bradley and Desmond, Montpellier Codex, 5-6. On Adam's life, see Falck, "Adam de la Halle."

129 See Symes, "'School of Arras.'”

130 "Entre Adan et Hanikel" / "Chief bien seantz" / APTATUR, "Aucun se sont loe" / "A Dieu commant" / SUPER TE, and "De ma dame vient" / “Diex, comment porroie" / OMNES.

${ }^{131}$ On the date of Mo fascicle 8, probably in the early fourteenth century, see Bradley and Desmond, introduction to Bradley and Desmond, Montpellier Codex, 4.

132 The index for a now lost motet book, Bes, gives text incipits for three of these six motets: "Bien met amours" / "Dame, alegies ma grevance" / A PARIS, "En mai, quant rosier" / "L'autre jour, par un matin" / HE RESVELLE TOI ROBIN, and “Mout me fu” / "Robin m'aime" / PORTARE. The fragmentary leaf Reg preserves two: “Dame bele" / "Fi, mari" / NUS N'IERT JA JOLIS and "En mai, quant rosier" / "L'autre jour, par un matin" / HE RESVELLE TOI ROBIN.

133 The two unica are "Theoteca Virgo geratica" / "Las, pour quoi" / QUI PRANDOIT and "Se je suis" / "Jolietement" / OMNES.

${ }^{134}$ I have argued above that this true of "Se je suis" / "Jolietement" / OMNES and of "Dame bele" / "Fi, mari" / NUS N'IERT JA JOLIS. Pesce ("Beyond Glossing," 29) shows that the 
citation, these six motets have been tentatively regarded as his own creations, their absence from Ha notwithstanding. ${ }^{135}$ Yet whether these works are actually by Adam or not, the seventh and eighth fascicles of Mo show a clear proximity to his output. David Maw has recently demonstrated that these concluding two fascicles of Mo preserve a body of works-many of them also unique-by Pierre de la Croix. Maw's proposition that "someone close to Petrus de Cruce and his circle assembled this collection" ${ }^{\prime 136}$ resonates with the parallel case of Adam de la Halle. Author figures are rendered invisible in Mo by an absence of explicit attributions that is typical of libri motettorum in general, and that stands in stark contrast to trouvère manuscripts, such as Adam's own Ha. Nevertheless, the motet collections in Mo fascicles 7 and 8 display a preoccupation with particular compositional personalities: Pierre, Adam, and possibly others who remain unknown. This would seem to be a further basis on which to challenge current tendencies to presume a direction of influence from the motets of Mo fascicle 7 to Adam, and, more generally, from motets to polyphonic rondeaux.

\section{Conclusions}

This article has sought to illuminate compositional preferences, evident throughout the thirteenth century, for a particular kind of motet tenor-a relatively short and simple plainchant melody with two principal cadence pitches, a tone apart, that can be set in tonal opposition. Such motet tenors support upper-voice quotations of vernacular song melodies and formal structures, and they stand in contrast to the longer, wider-ranging, and more intricately patterned chant melismas that are favored as tenors in organum and clausula compositions in the Magnus liber. Compositional interest in musically rather nondescript motet tenors is already evident (thirty years earlier than typically presumed) in one of the oldest surviving sources of thirteenth-century polyphony, F, and becomes even more prevalent in later thirteenth-century

motet "Mout me fu" / "Robin m'aime" / PORTARE quotes the monophonic rondeau "Robin m'aime" that opens Adam's Jeu d'Adam and there seems no reason to doubt that the refrain from Adam's Jeu de Robin et de Marion is quoted in the tenor of "En mai, quant rosier" / "L'autre jour, par un matin" / HE RESVELLE TOI ROBIN. On this motet and its tenor refrain, see Butterfield, “Vernacular Music and Poetry," 218-20.

135 The authorship of these six motets is designated "uncertain" in the works list in Falck, "Adam de la Halle." They are included as possible compositions by Adam in Adam de la Halle, Lyric Works.

${ }^{136}$ Maw, "Je le temoin en mon chant," 181. 
manuscripts, especially in the repertoire of vernacular double motets in Mo and Ba. In these later sources, the chosen tenors and their characteristics are also increasingly consistent. Although IUSTUS and HODIE appear in just one or two early motet compositions-supporting upper voices with an exceptionally high dependence on song forms and quotations-later thirteenth-century motet composers repeatedly return to and exploit the potential of the short and simple OMNES melody to support song forms and quotations. The meaning of the tenor word IUSTUS (justice) is of little consequence in either of its extant two-voice motet compositions. All three appearances of the two-voice motet material on the tenor HODIE are differently texted, the interchangeability of the tenor words HODIE, DIES, and VENIMUS being an indication that none of them was of particular semantic significance. On the other hand, tenor texts seem to increase in importance in later thirteenth-century three-voice motets, perhaps because of the increase in textual possibilities presented by polytextual upper voices. The meaning of tenor words such as OMNES, and especially APTATUR, seems to have been at least part of their attraction for multivoiced motets, and even Adam de la Halle's unique SUPER TE (above you) tenor could have appealed as a self-referential pun.

The most striking and consistent feature of the later thirteenth-century motet tenors examined here is, however, their modal consistency. The tenors OMNES, APTATUR, and SUPER TE all have $\mathrm{F}$ as their home or final pitch, using $\mathrm{G}$ as a harmonic alternative. The same is true of the vernacular rondeau tenor NUS N'IERT JA JOLIS. In the case of OMNES and APTATUR, the fact that alternative pitch levels for these melismas—on c, at the conventional transposition of a fifthare found in chant sources makes the preference for their $\mathrm{F}$ final incarnations in motets all the more notable. In late thirteenth-century English motets on freely composed pedes, lower voices that alternate between $\mathrm{F}$ and $\mathrm{G}$ overwhelmingly predominate: the famous canonic double pes of the "Sumer is icumen in" canon, for instance, opposes F and c with G and b. ${ }^{137}$ Peter Lefferts also identifies a group of four compositions whose pes foundations are characterized by an F-CF motion, the very same oscillation between the final pitch, F, and $\mathrm{C}$ a fourth below as at the opening of the tenor APTATUR. ${ }^{138}$ Significantly, a distinct preference for an F final is also evident in Adam de la Halle's corpus of sixteen polyphonic rondeaux in $\mathbf{H a}$, twelve of which close on a final F/f-c or F-f chord. A majority of the twenty-nine vernacular song melodies that appear as French motet tenors also have an $\mathrm{F}$ final (with $\mathrm{G}$ as a second choice). The use of an $\mathrm{F}$ final in polyphony such as the pes motets or the polyphonic rondeaux, whose lowest voices are freely composed, may be merely a notational convention, one that might best accommodate particular

${ }^{137}$ See Sanders, “Worcester Polyphony. " See also Lefferts, "Motet in England," 73.

${ }^{138}$ Lefferts, "Motet in England," 92, 97. 
vocal ranges. It nevertheless remains remarkable that this preference should be shared by late thirteenth-century motets on vernacular and plainchant tenors (which usually respect conventions for the original church modes of the chant quotations), English pes motets, and polyphonic rondeaux. This supports the hypothesis advanced above of a common musical currency between these diverse polyphonic genres, despite their different stylistic registers and their use (or not) of musical quotations. ${ }^{139}$

There are considerable similarities between the late thirteenth-century plainchant tenors that were chosen for their potential to support vernacular song idioms in the upper voices of motets and the genuine vernacular songs that served as tenors in such compositions, the song forms and characteristics of which-also adopted in their upper voices, as Everist has shownwere inherent and explicit. ${ }^{140}$ The OMNES tenor in the copy of "Dieus ou pourrai" / "Ce sont" / OMNES in the early fourteenth-century manuscript Tu (30v), for instance, was labeled with the French refrain text "Ki n'at point d'argent" (vdB 105). Since concordances for this refrain survive in text-only sources-in L'art d'amour, the French translation of Ovid's Ars amatoria, and in collections of proverbs-its melody cannot be verified. Yet presumably the refrain's music was similar enough to the OMNES tenor to mislead the scribe of $\mathbf{T u}$, who mistook this plainchant quotation for a vernacular refrain. The same phenomenon is evident in certain English motets that apply the label "pes," indicating a newly composed polyphonic foundation, to genuine plainchant tenors: PRO PATRIBUS, a widely used thirteenth-century tenor that opens $\mathrm{F}-\mathrm{a}-\mathrm{C}$, is mistaken for a pes, as is a version of the chant "Regina celi laetare."141

On the surface, English pes motets might seem a somewhat distant phenomenon, geographically and chronologically, from thirteenth-century French motets. Although connections between these repertoires are not always immediately apparent, they merit further investigation. Relationships between practices usually separately characterized as English and French are particularly evident in the eighth fascicle of Mo, admittedly a late witness to the thirteenth-century motet tradition. ${ }^{142}$ Two unique motets in Mo fascicle 8, for instance, whose lowest voices are simply designated “Tenor," are evidently built, not on any plainchant quotation, but on formulaic, pes-like foundations. The lowest voice of "Dieus, comment" / "Vo

139 Thomas Walker has also drawn attention to melodic similarities between specific French song tenors and plainchant melodies: Walker, "Sui tenor francesi."

${ }^{140}$ Everist, "Motets, French Tenors."

${ }^{141}$ See Lefferts, "Motet in England," 7n7.

${ }^{142}$ On Mo 8's English connections, see Desmond, “Texture, Rhythm, and Stylistic Groupings." 
vair oel" / TENOR simply oscillates between two pitches—its final, C, and D-while the musical basis of the Latin motet "Amor potest" / "Ad amorem" / TENOR continually cycles around three notes, E, G, and its final, F. ${ }^{143}$ The English practice of employing a double pes offers perhaps the only convincing parallel for the unique thirteenth-century double tenor motet "Je ne chant" / "Talens" / APTATUR / OMNES. Moreover, in "Thomas gemma" / "Thomas cesus"— a late thirteenth- or early fourteenth-century English double pes motet celebrating Thomas of Canterbury (d. 1170) and Thomas of Dover (d. 1295) — an initial F-C-F movement in the first pes (identical to the opening of the APTATUR tenor) is combined with an F-G-F movement in the second pes (identical to the opening of the OMNES tenor). ${ }^{144}$ The two pedes that provide a freely composed harmonic foundation for the upper voices of "Thomas gemma" / "Thomas cesus" thus replicate exactly the opening combination of the two tenor quotations in "Je ne chant" / “Talens" / APTATUR / OMNES. Such a coincidence need not be the result of any direct influence between particular French and English motets, but rather suggests their shared heritage within a tradition of polyphonic music making — perhaps a predominantly oral tradition —of which this essential harmonic behavior was the basis.

The remarks about motet tenors frequently quoted from medieval theorists - that they generate and support a motet composition and should be chosen first—are slightly at odds with the rather more pragmatic conceptualization of tenor selections and treatments highlighted above. Tenors were, for instance, specially sought out to facilitate particular upper-voice techniques (repetition or quotation) or, in the case of Adam's motet "Aucun se sont loe" / "A Dieu commant" / SUPER TE, in order to replicate the lowest voice of a preexisting polyphonic rondeau. An indication that motet tenors could be interchangeable and replaceable is offered by the unique circumstance of the motet "Flor de lis" / "Je ne puis." This double motet receives the vernacular song tenor DOUCE DAME QUE J'AIM TANT in Mo fascicle $5(214 \mathrm{v})$ and a different melody with the Latin text PROH DOLOR (for which a chant source is as yet unidentified) at its only other appearance, in Ba (19r). "Je ne chant" / "Talens" / APTATUR / OMNES, on the other hand, shows that tenor quotations were also combinable. Such examples, previously unrecognized or little known, encourage analytical approaches to thirteenth-century motets that remain open to both the pragmatism and the ingenuity of tenor selections and manipulations, and that do not underestimate the possibility for one musical quotation to be substituted for, suggested by, or combined with, another.

${ }^{143}$ These two motets are found in Mo, 360r-361v and 376v-377r respectively.

${ }^{144}$ See the transcription of the double pes in Lefferts, "Motet in England," 97. 
The simple harmonic foundations favored in some thirteenth-century motets on plainchant tenors, and in most polyphonic rondeaux and motets based on pedes, represent a different compositional ethos to the reworking of musically interesting and complicated chant melismas as polyphonic tenors in the organa and clausulae of the Magnus liber. This chant-based Magnus liber repertoire constitutes basically the only polyphonic evidence that survives from the early thirteenth century. By contrast, extant written records of newly composed vernacular polyphony are an exclusively late thirteenth-century phenomenon, and a composer such as Adam de la Halle-with securely attributed works that comprise monophonic songs, polyphonic rondeaux, and motets-remains a wholly exceptional figure. Adam's rondeaux represent the entirety of the extant thirteenth-century musical evidence for this polyphonic genre, but the testimony of additional rondeaux texts in $\mathbf{P a B}$ is proof that polyphonic rondeaux were not Adam's exclusive preserve. There may, therefore, be many more polyphonic quotations between motets and rondeaux that remain invisible because they are beyond Adam's immediate realm, and the paucity of manuscript sources for vernacular polyphony that was not based on plainchant should not be taken at face value. Although only late thirteenthcentury English sources offer explicit written evidence for entirely newly composed motets, this article has shown that certain plainchant tenor motets within an earlier and "central" thirteenthcentury French tradition adopt essentially the same kinds of harmonic foundations as these freely composed pieces. This suggests that pes-like lower voices, recorded only in late thirteenth-century English sources, were, in fact, part of a more universal practice of making vernacular polyphony that was current also in France from at least the 1240s. Such a hypothesis might seem to threaten the elite status of the motet genre, one whose roots in the notated liturgical polyphony of the Magnus liber organi are typically emphasized by scholars, who have also preferred to minimize its dependence on the less elevated and monotextual polyphonic rondeaux. On the contrary, the plainchant tenors examined here reveal a previously unappreciated level of sophistication on the part of motet composers-their ability to achieve simple harmonic underpinnings that offer maximal potential as polyphonic foundations while maintaining the convention that motets should be built on plainchant quotations. The creation of motets that quote and thematize vernacular chansons in simultaneous combination with a preexisting tenor quotation is made possible only by an intimate knowledge of both liturgical plainchant melodies and the practices of worldly French song.

\section{Works Cited}


Manuscript Sources

\begin{tabular}{|l|l|}
\hline ArsC & Paris, Bibliothèque de l'Arsenal, 8521 \\
\hline Ba & Bamberg, Staatsbibliothek, Lit. 115 (formerly Ed.IV.6) \\
\hline Bes & Besançon, Bibliothèque municipale, I, 716 \\
\hline CaB & $\begin{array}{l}\text { Cambrai, Médiathèque d'aglomération (formerly Bibliothèque } \\
\text { municipale), B 1328 }\end{array}$ \\
\hline Da & Darmstadt, Hessische Landesbibliothek, 3471 \\
\hline Douce 308 & Oxford, Bodleian Library, Douce 308 \\
\hline F & Florence, Biblioteca Medicea Laurenziana, Plut. 29.1 \\
\hline Ha & $\begin{array}{l}\text { Paris, Bibliothèque nationale de France, fr. 25566, “Adam de la Halle } \\
\text { manuscript” (= trouvère manuscript W) }\end{array}$ \\
\hline Hu & Burgos, Monasterio de Las Huelgas, 11 (formerly IX) \\
\hline Lo33327 & London, Westminster Abbey 33327 \\
\hline Mo & $\begin{array}{l}\text { Montpellier, Bibliothèque interuniversitaire, Section de médecine, } \\
\text { H. 196 }\end{array}$ \\
\hline MüA & $\begin{array}{l}\text { Munich, Bayerische Staatsbibliothek, Mus.ms. 4775 (gallo-rom. 42) and } \\
\text { fragments in Berlin, Staatsbibliothek zu Berlin, Musikabteilung 55 } \\
\text { MS 14 (formerly in the private library of Johannes Wolf, Berlin) }\end{array}$ \\
\hline N & $\begin{array}{l}\text { Paris, Bibliothèque nationale de France, fr. 12615, “Noailles } \\
\text { chansonnier" }\end{array}$ \\
\hline Pa11411 & Paris, Bibliothèque nationale de France, lat. 1114 \\
\hline PaB & Paris, Bibliothèque nationale de France, fr. 12786 \\
\hline PsAr & Paris, Bibliothèque nationale de France, lat. 11266 \\
\hline Reg & $\begin{array}{l}\text { Rome, Biblioteca Apostolica Vaticana, Regina 1543 (fragments) } \\
\text { Paris, Bibliothèque nationale de France, fr. 372 }\end{array}$ \\
\hline Renart C & Paris, Bibliothèque nationale de France, fr. 1593 \\
\hline Renart F & Turin, Biblioteca Reale, vari 42 \\
\hline Tu & $\begin{array}{l}\text { Worau, Bibliothek des Augustiner Chorherrenstifts, 23 (Fragment 118D) } \\
\text { (Heinemanttel, Herzog August Bibliothek, Cod. Guelf. 628 Helmst. }\end{array}$ \\
\hline Vorau & $\begin{array}{l}\text { Wolfenbüttel, Herzog August Bibliothek, Cod. Guelf. 1099 Helmst. } \\
\text { (Heinemann no. 1206) }\end{array}$ \\
\hline $\mathbf{1}$ & Pariothèque nationale de France, lat. 15613 \\
\hline
\end{tabular}


Editions and Secondary Literature

Adam de la Halle. The Lyric Works of Adam de la Hale: Chansons, Jeux-partis, Rondeaux, Motets.

Edited by Nigel Wilkins. Corpus mensurabilis musicae 44. Rome: American Institute of Musicology, 1967.

Anderson, Gordon A. "Clausulae or Transcribed Motets in the Florence Manuscript?" Acta musicologica 42, nos. $3 / 4$ (1970): 109-28.

------. “Newly Identified Tenor Chants in the Notre Dame Repertory." Music and Letters 50, no. 1 (1969): 158-71.

Aubry, Pierre. Cent motets du XIIIe siècle, publiés d'après le manuscrit Ed. IV. 6 de Bamberg. 3 vols. Paris: A. Rouart, Lerolle, 1908.

Baltzer, Rebecca A. “Notation, Rhythm, and Style in the Two-Voice Notre Dame Clausula." 2 vols. PhD diss., Boston University, 1974.

------. “The Polyphonic Progeny of an Et gaudebit: Assessing Family Relations in the ThirteenthCentury Motet." In Hearing the Motet: Essays on the Motet of the Middle Ages and Renaissance, edited by Dolores Pesce, 17-27. New York and Oxford: Oxford University Press, 1997.

Bayart, Paul. "Les anciens offices de saint Winnoc et de saint Oswold." Tribune de saint Gervais 14, no. 3 (1908): 56-60.

Boogaard, Nico H. J. van den. Rondeaux et refrains du XIle siècle au début du XIVe. Bibliothèque française et romane. Ser. D, Initiation, textes et documents 3. Paris: Klincksieck, 1969.

Bradley, Catherine A. Polyphony in Medieval Paris: The Art of Composing with Plainchant. Cambridge, UK: Cambridge University Press, 2018.

Bradley, Catherine A., and Karen Desmond. Introduction to Bradley and Desmond, Montpellier Codex, 1-10.

------, eds. The Montpellier Codex: The Final Fascicle: Contents, Contexts, Chronologies. Woodbridge, UK: Boydell and Brewer, 2018.

Butterfield, Ardis. "'Enté': A Survey and Reassessment of the Term in Thirteenth- and Fourteenth-Century Music and Poetry." Early Music History 22 (2003): 67-101.

-----. Poetry and Music in Medieval France: From Jean Renart to Guillaume de Machaut. Cambridge, UK: Cambridge University Press, 2002.

-----. "Repetition and Variation in the Thirteenth-Century Refrain." Journal of the Royal Musical Association 116, no. 1 (1991): 1-23.

-----.."Vernacular Music and Poetry." In The Cambridge Companion to Medieval Music, edited by Mark Everist, 205-24. Cambridge, UK: Cambridge University Press, 2011. 
Clark, Suzannah. “'S'en dirai chançonete': Hearing Text and Music in a Medieval Motet." Plainsong and Medieval Music 16, no. 1 (2007): 31-59.

Crocker, Richard. "French Polyphony of the Thirteenth Century." In The Early Middle Ages to 1300, vol. 2 of The New Oxford History of Music, edited by Richard Crocker and David Hiley, 636-78. Oxford: Oxford University Press, 1990.

Curran, Sean. "Feeling the Polemic of an Early Motet." In Polemic: Language as Violence in Medieval and Early Modern Discourse, edited by Almut Suerbaum, George Southcombe, and Benjamin Thompson, 65-94. Farnham, UK: Ashgate, 2015.

Desmond, Karen. “Texture, Rhythm, and Stylistic Groupings in Montpellier 8 Motets.” In Bradley and Desmond, Montpellier Codex, 139-60.

Dillon, Emma. The Sense of Sound: Musical Meaning in France, 1260-1330. New Cultural History of Music. New York: Oxford University Press, 2012.

Everist, Mark. French Motets in the Thirteenth Century: Music, Poetry and Genre. Cambridge, UK: Cambridge University Press, 1994.

------. "Machaut's Musical Heritage." In A Companion to Guillaume de Machaut, edited by Jennifer Bain and Deborah McGrady, 143-58. Leiden: Brill, 2012.

------. “Motets, French Tenors, and the Polyphonic Chanson ca. 1300.” Journal of Musicology 24, no. 3 (2007): 365-406.

------, ed. Les organa à deux voix pour la messe (de l'Assomption au commun des saints) du manuscrit de Florence, Biblioteca Medicea-Laurenziana, Plut. 29.1. Vol. 4 of Le magnus liber organi de NotreDame de Paris. Edited by Edward H. Roesner. Monaco: Éditions de L'Oiseau-Lyre, 2002.

-----. “The Polyphonic Rondeau c. 1300: Repertory and Context.” Early Music History 15 (1996): 59-96.

-----.."The Refrain Cento: Myth or Motet?” Journal of the Royal Musical Association 114, no. 2 (1989): 164-88.

------. “The Rondeau Motet: Paris and Artois in the Thirteenth Century." Music and Letters 69, no. 1 (1988): 1-22.

Falck, Robert. “Adam de la Halle.” Grove Music Online. Accessed April 10, 2018. https: / / doi.org/10.1093/gmo/9781561592630.article.00163.

Flotzinger, Rudolf. Der Discantussatz im Magnus liber und seiner Nachfolge. Wiener musikwissenschaftliche Beiträge 8. Vienna, Cologne, and Graz: Hermann Böhlaus, 1969.

Frobenius, Wolf. "Zum genetischen Verhältnis zwischen Notre-Dame-Klauseln und ihren Motetten." Archiv für Musikwissenschaft 44, no. 1 (1987): 1-39.

Gennrich, Friedrich. Bibliographisches Verzeichnis der französischen Refrains des 12. und 13. Jahrhunderts. Summa musicae medii aevi 14. Langen bei Frankfurt: F. Gennrich, 1964. 
Goudesenne, Jean-François. “L'Office de s. Winoc de Bergues (Flandres, XIe siècle) est-il à l'origine d'une teneur dans les motets du XIIIe siècle? Recherches sur la teneur Aptatur dans les motets des manuscrits de Montpellier et de Bamberg." In The Di Martinelli Music Collection (KULeuven, University Archives): Musical Life in Collegiate Churches in the Low Countries and Europe: Chant and Polyphony, Yearbook of the Alamire Foundation 4, edited by Bruno Bouckaert and Eugeen Schreurs, 283-95. Leuven: PEER, 2000.

Hofmann, Klaus. Untersuchungen zur Kompositionstechnik der Motette im 13. Jahrhundert, durchgeführt an den Motetten mit dem Tenor IN SECULUM. Neuhausen-Stuttgart: Hänsler, 1972.

------. “Zur Entstehungs- und Frühgeschichte des Terminus Motette.” Acta musicologica 42, nos. 3 / 4 (1970): 138-50.

Huot, Sylvia. Allegorical Play in the Old French Motet: The Sacred and the Profane in ThirteenthCentury Polyphony. Stanford, CA: Stanford University Press, 1997.

Ibos-Augé, Anne. “. . Q Que ne dit 'cief bien seans': Quoting Motets in Montpellier 8." In Bradley and Desmond, Montpellier Codex, 211-30.

Johannes de Grocheio. Ars musice. Edited and translated by Constant J. Mews, John N. Crossley, Catherine Jeffreys, Leigh McKinnon, and Carol J. Williams. Kalamazoo, MI: Medieval Institute Publications, 2011.

Leech-Wilkinson, Daniel. Compositional Techniques in the Four-Part Isorhythmic Motets of Philippe de Vitry and His Contemporaries. 2 vols. New York: Garland, 1989.

Lefferts, Peter Martin. “The Motet in England in the Fourteenth Century.” PhD diss., Columbia University, 1983.

Ludwig, Friedrich. Repertorium organorum recentioris et motetorum vetustissimi stili. 2 vols. in 3. Edited by Luther A. Dittmer. New York: Institute of Mediæval Music, 1964-78. First published 1910.

Maw, David. "Je le temoin en mon chant: The Art of Diminution in the Petronian Triplum." In Bradley and Desmond, Montpellier Codex, 161-83.

Norwood, Patricia P. "Evidence concerning the Provenance of the Bamberg Codex." Journal of Musicology 8, no. 4 (1990): 491-504.

Pacha, Danielle Joanne. "The VERITATEM Family: Manipulation, Modeling and Meaning in the Thirteenth-Century Motet." PhD diss., Washington University, 2002.

Page, Christopher. Discarding Images: Reflections on Music and Culture in Medieval France. Oxford: Clarendon Press, 1993.

Pesce, Dolores. “Beyond Glossing: The Old Made New in Mout me fu grief / Robin m'aime / Portare." In Hearing the Motet: Essays on the Motet of the Middle Ages and Renaissance, edited by Dolores Pesce, 28-51. New York and Oxford: Oxford University Press, 1997. 
Pfändtner, Karl-Georg. “Zum Entstehungsraum der Bamberger Motettenhandschrift Msc.Lit.115: kodikologische und kunsthistorische Argumente." Acta musicologica 84, no. 2 (2012): 161-66.

Planchart, Alejandro Enrique. “The Flower's Children.” Journal of Musicological Research 22, no. 4 (2003): 303-48.

Rothenberg, David J. “The Marian Symbolism of Spring, ca. 1200-ca. 1500: Two Case Studies.” This Journal 59, no. 2 (2006): 319-98.

Saint-Cricq, Gaël. "Formes types dans le motet du XIIIe siècle: étude d'un processus répétitif." 2 vols. PhD diss., University of Southampton, 2009.

-----. "A New Link between the Motet and Trouvère Chanson: The pedes-cum-cauda Motet." Early Music History 32 (2013): 179-223.

Saltzstein, Jennifer. "Rape and Repentance in Two Medieval Motets." This Journal 70, no. 3 (2017): 583-616.

------. The Refrain and the Rise of the Vernacular in Medieval French Music and Poetry. Gallica Series 30. Cambridge, UK: D. S. Brewer, 2013.

Sanders, Ernest H. “Worcester Polyphony.” Grove Music Online. Accessed April 11, 2018. https:/ / doi.org/10.1093/gmo/9781561592630.article.30564.

Symes, Carol. A Common Stage: Theater and Public Life in Medieval Arras. Ithaca, NY: Cornell University Press, 2007.

------. “Repeat Performances: Adam de la Halle, Jehan Bodel, and the Reusable Pasts of Their Plays." In Collections in Context: The Organization of Knowledge and Community in Europe, edited by Karen Fresco and Anne D. Hedeman, 275-87. Columbus: The Ohio State University Press, 2012.

-----. "The 'School of Arras' and the Career of Adam." In Musical Culture in the World of Adam de la Halle, edited by Jennifer Saltzstein, 21-50. Brill's Companions to the Musical Culture of Medieval and Early Modern Europe. Leiden and Boston: Brill, forthcoming (2019).

Tischler, Hans, ed., and Susan Stakel and Joel Relihan, trans. The Montpellier Codex. 4 vols. Recent Researches in the Music of the Middle Ages and Early Renaissance 2-8. Madison, WI: A-R Editions, 1978-85.

-----. The Style and Evolution of the Earliest Motets (to circa 1270). 3 vols. in 4. Musicological Studies 40. Ottawa: Institute of Mediæval Music, 1985.

Walker, Thomas. "Sui tenor francesi nei mottetti del '200." Schede medievali: Rassegna dell'Officina di studi medievali 3 (1982): 309-36.

Zayaruznaya, Anna. Upper-Voice Structures and Compositional Process in the "ars nova" Motet. Royal Musical Association Monographs 32. London and New York: Routledge, 2018. 


\begin{abstract}
This article explores trends and motivations in the selection of plainchant and vernacular song quotations as the foundations of thirteenth-century motets. I argue that particular tenor melodies that received only cursory treatment in the liturgical polyphony of the Magnus liber organi were adopted in motets on account of their brevity and simplicity, characteristics that enabled their combination with upper-voice song forms and refrain quotations. Demonstrating a preference for short and simple tenors within the earliest layers of the motet repertoire, I trace the polyphonic heritage of the tenor OMNES, whose simple melody enabled its combination with another more obscure plainchant quotation, APTATUR, in a unique double tenor motet. I propose that motet creators - while sensitive to the semantic connotations of tenor texts-exploited the musical ability of tenor quotations to be combined with or stand in for other musical quotations. Newly identifying a plainchant tenor source in a motet by Adam de la Halle, I show that Adam's polyphonic motet citations of his own three-voice polyphonic rondeaux were achieved by careful selection of motet tenors to replicate the freely conceived lowest voices of these preexisting rondeaux. The article further reveals profound modal and melodic similarities between quotations chosen as thirteenth-century motet tenors and the newly composed lowest voices of polyphonic rondeaux and English pes motets. It offers new perspectives on the relationship between the "elite" genre of the motet and types of polyphony that are less well attested in written sources, often considered to inhabit a more "popular" realm of musical practice.
\end{abstract}

Keywords: quotation, intertextuality, compositional process, motet, rondeau, refrain 